\title{
Food dispersion systems process stabilization. A review.
}

\section{Andrii Goralchuk, Olga Grinchenko, Olga Riabets, Oleg Kotlyar}

\author{
Kharkiv State University of Food Technology and Trade, Kharkiv, Ukraine
}

Keywords:

Emulsion

Foam

Stabilization

Rheology

Layers

\section{Article history:}

Received 28.11.2018

Received in revised form 15.08.2019

Accepted 28.11.2019

\section{Corresponding author:}

Andrii Goralchuk

E-mail:

abgora@gmail.com

DOI: $10.24263 / 2304-$

974X-2019-8-4-4

\section{Abstract}

Introduction. The overview is given to systematize information on the indicators, affecting the production and stabilization of foams and emulsions, for applying the existing regularities for more complex dispersed (polyphase) systems.

Materials and methods. Analytical studies of the production and stabilization of foams and polyphase dispersed systems published over the past 20 years. The research focuses on the foams, emulsions, foam emulsion systems and the systems, being simultaneously foam, emulsion and suspension.

Results and discussion. Though foams and emulsions have similarities and their production differs in the dispersion rate, determined by the rate of surfactants adsorption. Emulsifying is faster than foaming, therefore, the production of foam emulsions can be sequential only. Coalescence, as a destruction indicator, is typical of foams and emulsions alike, and it is determined by the properties of surfactants. Other indicators are determined by the features of the dispersion medium. The study systematized the factors, ensuring the stability of dispersion systems. The structural mechanical factor is effective in stabilizing foams and emulsions. It is implemented by the usage of proteins only, or solids with partial soaking, or a combination of proteins and low-molecular surfactants or a combination of proteins and polysaccharides. The structural mechanical factor for polyphase systems stabilization, in particular, for foam emulsions, is based on selecting surfactants to regulate rheological properties of interface adsorption layers, the sequence of dispersion phases, which ensures their spatial location in the food product.

Conclusions. The rheological properties of interface adsorption layers, containing proteins, surfactants, polysaccharides and high viscosity of the dispersion medium play the vital part in ensuring the stability of food dispersion systems. 


\section{Introduction}

Many culinary and confectionary products are characterized by the polyphase structure. The phases may differ in content, aggregate state, ingredients, and the degree of dispersion. Food dispersion systems are thermodynamically unstable. These systems require the development of effective solutions to strengthen their process stability. In other words, it is necessary to increase the time during which the food product will not be affected. Extensive pure and applied studies have been discussing the production and stabilization of foams, emulsions, suspensions, and foods. The fundamental research into the production and stabilization of foams and emulsions, which unite the known evidence-based data, determined by the system ingredients and the way of their production, is continuously developing and scientifically expanding. However, fundamental papers that would ensure polyphase foods (systems containing several different phases) production and stability are nearly non-existent. Therefore, the development and intensification of process technologies for heterogeneous polyphase foods are inhibited. Accordingly, it is necessary to analyze scientific data on producing and stabilizing heterogeneous systems with a single continuous phase - foams and emulsions and their further development for polyphase dispersed structure foods.

\section{Materials and methods}

The analytical examination of the papers on the production and stabilization of emulsions, foams and polyphase dispersed systems over the past 20 years.

The research focuses on the foams, emulsions, foam emulsion systems and the systems, being simultaneously foam, emulsion and suspension. The study analyzes surfactants and stabilizers, used to provide dispersion systems stability.

\section{Results and Discussion}

\section{The production foams and emulsions, process differences and similarities}

Foams are thermodynamically unstable systems, with a gaseous dispersed phase and a liquid or solid dispersion. No clear size ranges of bubble have been reported in the literature. It is noted that the gas bubble size fluctuates from several micrometers to several centimeters [1]. Depending on the continuous phase content, bubbles have different shapes - from spherical (provided low concentration phase) to dodecahedric (provided high concentration phase). Foam stability is influenced by various factors, in particular: the nature and concentration of the foaming agent, temperature, viscosity and $\mathrm{pH}$ of the dispersion medium, the surface tension of solutions, the introduction of electrolytes into the liquid phase, different foods as solid particles, fatty raw materials [2,3]. However, their impact on the foam stability has been studied insufficiently and further work is to be performed in this respect.

Foams are manufactured in two ways [1]. The first is in air dispersion via frothing, intensive mixing or gas blowing through liquid. The other way is in gas or vapor liberation in liquid as a result of liquid boiling due to fast heating or pressure drop. For this purpose, gas is first dissolved in the liquid under high pressure. This approach is effectively implemented in spray whipping cream. 
Emulsions belong to lyophobic colloids, they are also thermodynamically unstable heterogeneous systems, which are two liquids that do not mix, but are distributed in each other. The discontinuous (dispersed) phase size varies from $10 \mathrm{~nm}$ to $50 \mu \mathrm{m}$. Depending on the discontinuous phase particle size emulsions are divided into nano-emulsions, microemulsions and emulsions (or macro emulsions). The specific feature of these emulsions is that micro-emulsions, unlike the others, are formed by themselves due to the ultra-low interfacial tension at about $0.1 \mathrm{mN} / \mathrm{m}$, the discontinuous phase particle size ranging from 10 to $100 \mathrm{~nm}$. Micro-emulsions are thermodynamically stable systems with high content of surfactants. In nano-emulsions particle size varies from 50 to $500 \mathrm{~nm}$. These emulsions are kinetically stable, have low surface tension $-1-10 \mathrm{mN} / \mathrm{m}$ and the medium content of surfactants. Emulsions are kinetically stable, have low interfacial tension and the dispersed particle size from $500 \mathrm{~nm}$ to $50 \mu \mathrm{m}[4,5]$. Nano-emulsions and emulsions have become practically used in foods.

Emulsions are classified according to two criteria: discontinuous phase concentration diluted $(\mathrm{C} \leq 0.1 \%)$, concentrated $(0.1 \% \leq \mathrm{C} \leq 74 \%)$ and highly concentrated $(\mathrm{C}>74 \%)$; dispersion medium polarity - direct (the dispersion medium is a polar liquid) and reverse (the dispersion medium is a non-polar liquid) [6].

It is necessary to carry out thorough examination of the processes occurring while forming and destroying foams and emulsions. The processes of forming and destroying foams and emulsions are quite similar. The formation of the dispersed system of a foam (Figure 1, a) or an emulsion (Figure 1, b) [6] is accompanied by three simultaneous processes:

- Discontinuous phase particles are deformed and broken;

- Srfactants are diffused in the newly created phase boundary surfaces and are adsorbed on them;

- Discontinuous phase particles collide, which leads to coalescence or repulsion.

Emulsions are produced using the methods of dispersion in emulsifying machines, rotary pulsers, homogenizers, ultrasound machines or via oil feeding through a network of micro-channels [7]. Emulsifying features availability of two liquids, which are not dissolved in each other, and the availability of surfactants, which ensure formation of the interface adsorption layer. The way of energy supply is important to ensure emulsion dispersion $[8,9]$.

To produce a dispersed system, it is necessary to put efforts into forming a new phase boundary surface, meaning that it is necessary to put efforts into destroying intermolecular forces (cohesion forces). Thermodynamically, lower degree of dispersion corresponds to the lower values of surface (in the foam) or interfacial (in emulsion) tension, which is ensured by including surfactants $[11,12]$. The breakup of drops, bubbles is counteracted by the capillary pressure, which is proportionate to the surface (interfacial) tension and is turned proportionate to the dispersion particle radius [11, 12]. The difference in the capillary pressure of two adjacent bubbles triggers gas diffusion and leads to their coalescence. Surfactants resist coalescence, due to the surface tension gradient $[13,14]$.

The foam and emulsion production processes are similar, but have certain differences. An important difference between the formation of foams and emulsions is in the dispersion rate. Emulsifying process is much faster than that of foam formation, which determines different rates of adsorption on various phase boundary surfaces. The second difference is the size of dispersion particles, which is normally lower in emulsion. In foams it is hard to separate foam formation from stabilization, since the destruction processes start at the stage of foam formation [15]. In emulsions (such as milk) fat particles can aggregate and coalesce only under the homogenizing pressure of 8-10 MPa after cooling [16, 17]. 


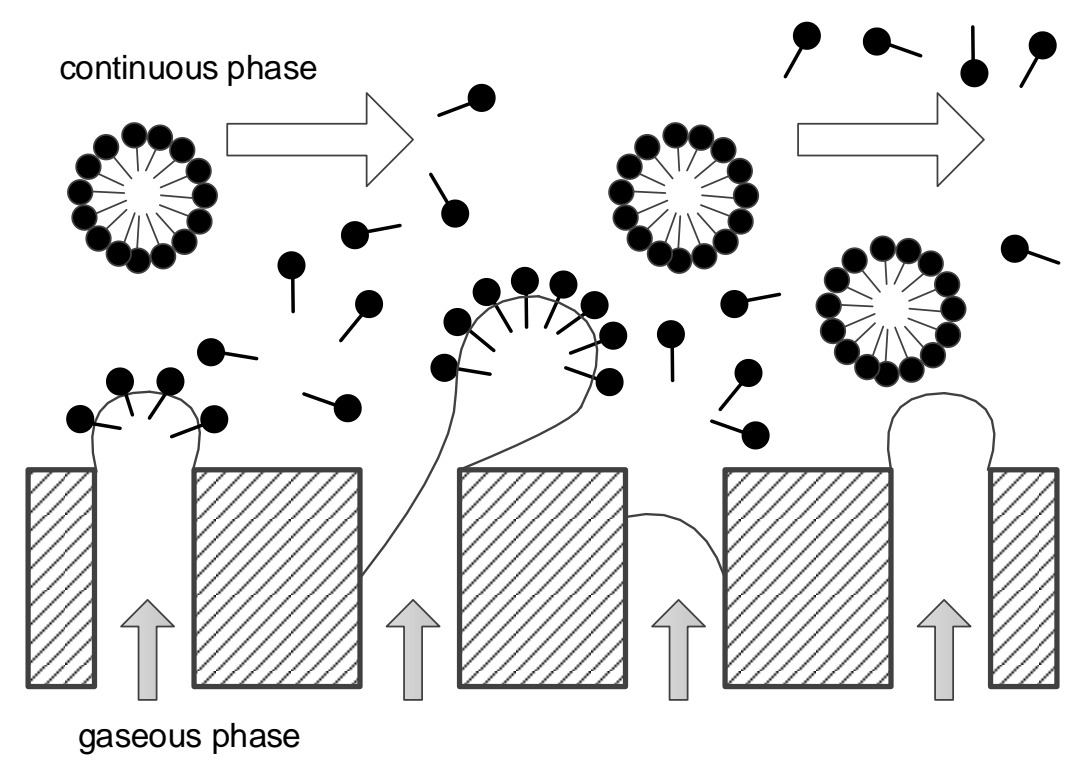

Figure 1, a. Foam formation [1].

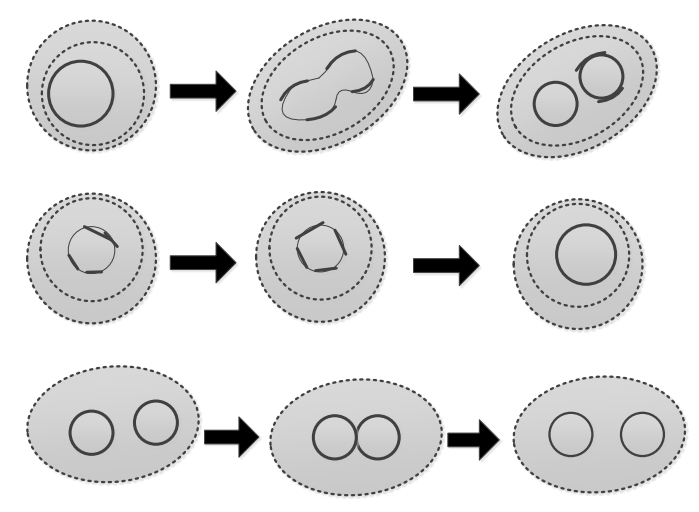

b)

Figure 1, b. Schematic representation of the various processes occurring during emulsion formation. The drops are depicted by thin lines and the surfactant by heavy lines and dots [3].

\section{Factors, affecting foam and emulsion destruction}

The coalescence rate depends on many factors: the conditions of foam and emulsion formation, size and homogeneity of continuous phase particles, the content of solid fat, crystal shape and size, the content of continuous phase, the kind and content of surfactants, the viscosity of dispersion medium $[18,19]$. 
The temperature impact on the stability of foams is rather complex due to numerous simultaneous competing processes. If the temperature rises, the pressure inside bubbles rises, too, as well as the surfactants solubility, the surface tension decreases, which improves foam stability. However, if the temperature rises, thermal vibrations of adsorbed molecules increase. That leads to the decrease in the mechanical strength of the surface layer, created by surfactant molecules. Furthermore, solution viscosity decreases, which raises the rate of liquid bleeding from the foam, and the conditions of surfactant polar group hydration change, which causes foam stability loss. However, in some foams, received using high-molecular substances (egg white), thermal treatment entails transition from the liquid dispersion medium to solid. The resulting foam becomes stable. The examples of these foams are fruit candy, marshmallow, sponge cake semi-finished product etc. Thus, the temperature effect on the foam stability is to be analyzed on case-by-case basis [20].

Accordingly, the integrated process of forming and destroying dispersed systems becomes obvious. In this respect, one of the main problems in producing dispersed systems is that of their stability, which is in finding the conditions, necessary for long keeping of homogeneously distributed continuous phase in the dispersion medium [21, 22]. The keeping time is determined by process objectives in each case. Therefore, it is generally possible to identify the factors of ensuring the process stability of dispersed systems.

Emulsion destabilization involves six processes: creaming, sedimentation, flocculation (agglomeration), phase inversion, coalescence and Ostwald ripening [22] (Figure 2, a). Foam destruction involves the following processes: syneresis and air bubble coalescence as well as disproportionation (the appearance of much bigger bubbles due to the bubble coalescence (merging)), the film rupture and thinning (Figure 2, b) [23, 24].

The surface tension gradient decreases the intensity of liquid bleeding from films [11, 13]. The motion of liquid in foam leads to the local changes in the liquid and gaseous phase ratio and it occurs due to two forces - the local gradient of capillary pressure and gravity force. It is expected that drainage phenomena are related to liquid bleeding from films, caused by the capillary pressure change, which leads to the liquid flow to thicker areas with lower pressure [26]. When the film thickness is below $10 \mathrm{~nm}$, it loses its integrity. At the same time gas bubbles merge (coalescence occurs), the bubbles volume increases, their quantity decreases and, eventually, foam hardens [26]. Film ruptures near the foam boundary entail the loss of the gaseous phase by the system [27]. Liquid from films gets in Plateau ribs. The channels, formed by these ribs, build a complex network for the liquid to flow out of foam due to the gravity force. The features of "wet foam" syneresis include the period of halfdecay - the time for the foam to half in volume [27].

Another important mechanism of foam destruction is disproportionation. Owing to higher capillary pressure in foams a smaller bubble, compared to bugger one, undergoes gas diffusion from the smaller to the bigger bubble through the dividing film [8, 28]. Eventually, larger bubbles grow due to smaller ones. The higher the degree of polydispersion is, the stronger the gas diffusion is. "Wet" foams with thick liquid layers firstly undergo liquid bleeding, which entails film thinning followed by the gas diffusion and film rupture [29].

Emulsions destruction has both similarities and differences. Emulsion creaming is due to the difference between the density between the continuous phase and medium, which leads to bulk separation. In other words, creaming is characterized by continuous phase rise, as oil density is lower than that of water. 


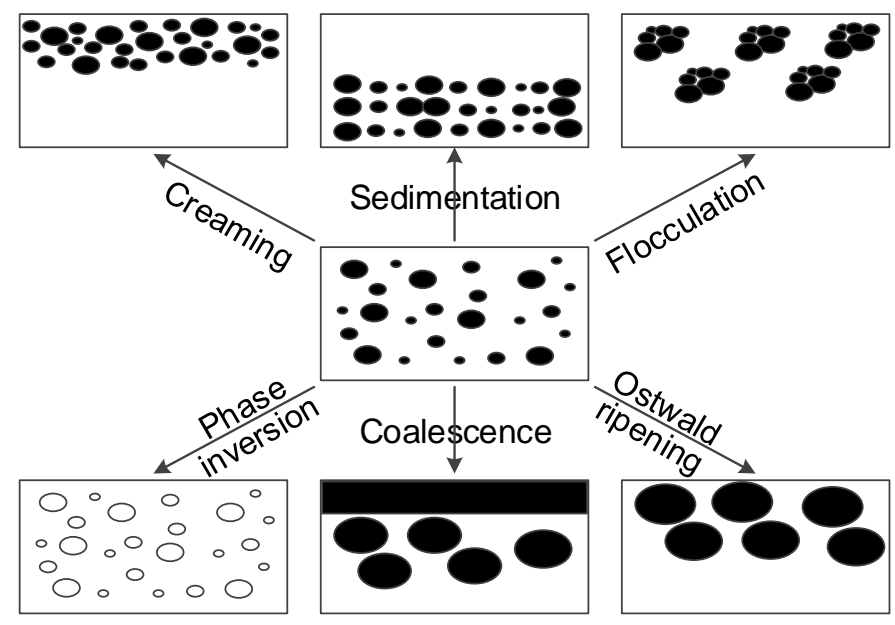

Figure 2, a. Emulsion destruction [3].
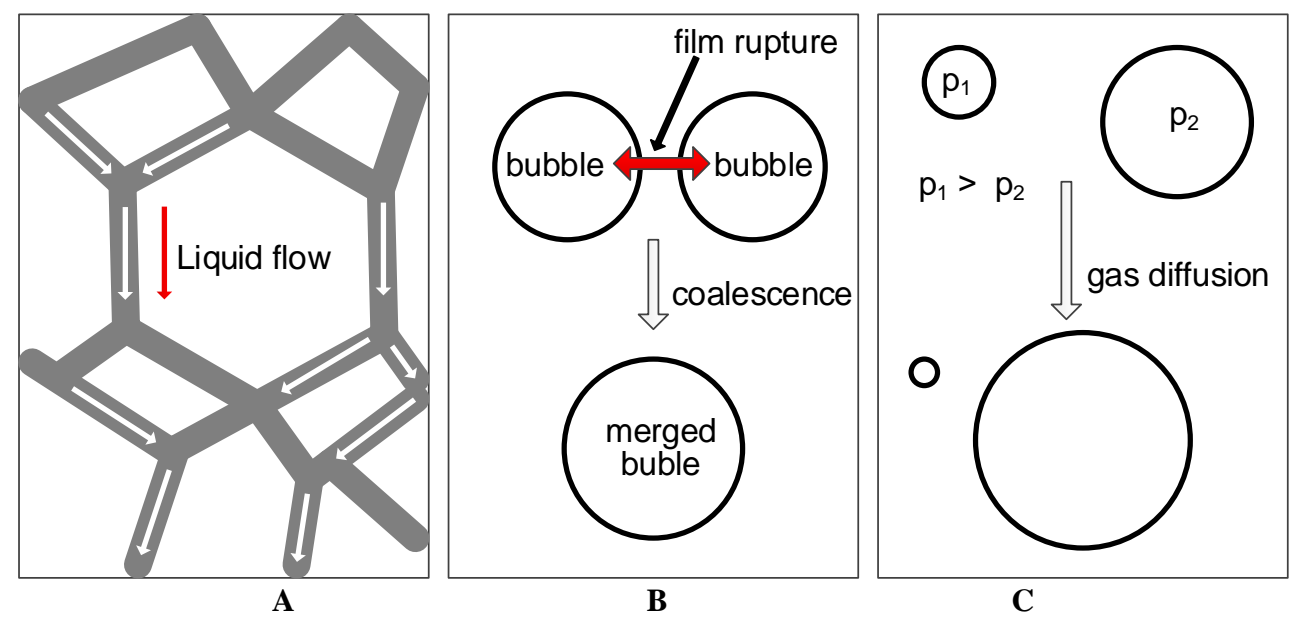

Figure 2, b. Foams [25] Gravitational drainage (A), Coalescence (B), Ostwald ripening (Disproportionation) (C).

Flocculation or agglomeration of the fat phase can occur in emulsion, provided van der Waals energy values are higher than those of the repulsion forces energy. During flocculation several oil droplets unite and form agglomeration, where each droplet stays intact, i.e. the droplet content does not shift. The process of coalescence is generally similar, and the only difference is that the droplet content unites, whereas the capillary pressure makes the resulting drop spherically shaped. In existing food emulsions the above processes are interrelated: creaming accelerates as the drop size increases through coalescence [30]. The effect is explained by the fact [29] that the oil drop lift rate rises proportionately to its squared radius. Flocculation and coalescence processes enlarge the radius of agglomerates or drops.

Studies also attend specifically to partial coalescence as a mechanism of emulsion instability $[31,32]$. This process is only between partially crystallized droplets, when a crystal 
of one droplet penetrates another. Liquid fat may flow out of the droplet, strengthen molecular binding, and create a bridge between two droplets [33] the mechanical force of the fat crystal binding is sufficient to stand capillary pressure, thus, protecting droplet shape and preventing their merging $[31,32]$.

Thus, coalescence is inherent in foams and emulsions, which is determined by the surface properties of surfactants. Such emulsion destruction processes as sedimentation, separation, Ostwald ripening and foam destruction processes - syneresis and disproportionation - are determined by the dispersion medium viscosity. The emulsion flocculation and phase inversion is due to surfactants activity.

\section{Factors, ensuring foam and emulsion stability}

Following the processes, occurring in dispersed systems destruction, three kinds of dispersion systems stability are singled out - aggregate, kinetic and phase. All of them are supported by different factors (Figure 3). The aggregate stability is the ability to keep unchanged size of dispersion particles over time, i.e. to resist coalescence. Kinetic stability is the system ability to keep unchanged continuous phase particle distribution within the system over time, i.e. to resist outflow or sedimentation of particles. Phase stability is the ability to keep unchanged nature of interaction between dispersed particles over time, which is important for the systems, where dispersed particles interact (flocculation) [34].

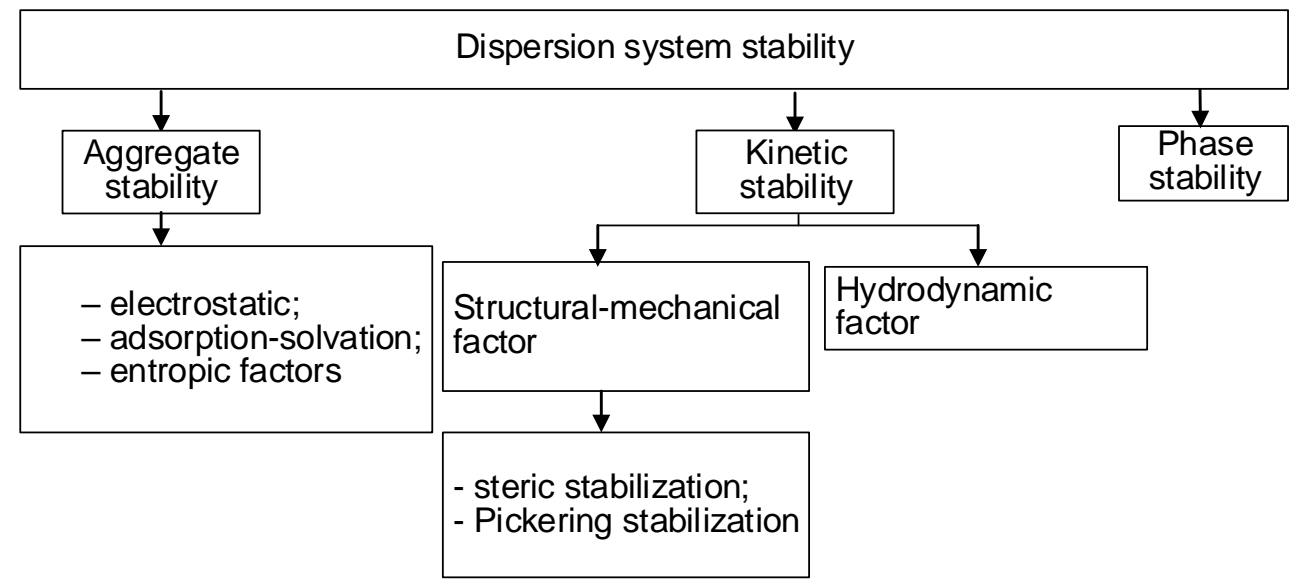

Figure 3. Factors, ensuring dispersion systems stability

The factors, ensuring the aggregate and kinetic stability of dispersed systems, include thermodynamic and kinetic ones. These factors can emerge severally or jointly.

The thermodynamic stabilization factors are [35]:

- Electrostatic;

- Adsorption-solvation;

- Entropic;

The electrostatic factor of stabilization is based on the theory, developed individually by Derjaguin, Landau, Verwey and Overbeek (DLVO). According to this theory, a double 
electric layer of ions is formed on the surface of the continuous phase particles, which brings about an electric power (energy) barrier (disjoining pressure). The latter prevents approximation of like-charged particles to the distances with intensive molecular attraction forces. It is not always possible to explain the stability of emulsions and foams, stabilized by nonionic surfactants, using the electrostatic factor. Nevertheless, the application of disjoining pressure models, under the DLVO theory, enables to unite several stabilization factors and forecast system behavior [36, 37].

The adsorption-solvation factor consists in forming a dispersion medium or an adsorbed molecule layer around the dispersed particle of solvation layers. When particles approach each other, solvation (adsorption) layers prevent their coalescence [34].

The stabilization entropic factor is determined by the thermal motion and mutual repulsion of flexible chains of surfactant macromolecules, partially bound to the dispersed particles as a result of adsorbing some of their parts. This mechanism of stabilization is definitely effective in low-concentration systems and in surfactant-containing systems with long flexible chains, oriented on the dispersion medium [34].

Kinetic factors include hydrodynamic and the structurally mechanical factor. The hydrodynamic factor is related to the speed of particles approximation and the speed of medium layer bleeding between them. The slowdown in the destruction of these systems may be achieved due to increasing the density and viscosity of the dispersion medium [34].

The structurally mechanical factor includes the steric stabilization factor and Pickering stabilization. The steric stabilization factor is determined by the formation of protective interface adsorption layers on the surface of dispersion particles, which prevent coagulation of dispersion particles owing to high-molecular substances or low-molecular non-ionic surfactants. Pickering stabilization of dispersion particles is due to the formation of a highdispersion solid particle protective barrier on their surface [37].

The study has established the effectiveness of stabilizing food dispersion systems (foams and emulsions) with structural-mechanical stabilization factor varieties - steric stabilization, provided the use of proteins, protein mixes [38], proteins with low-molecular surfactants [39, 40], protein complexes with polysaccharides [41, 42], and Pickering stabilization via using solid particles [43, 45], ethylcellulose [44], hydro dairy proteins, corn [46], fat particles [47], mustard flour, ginger flour [48] (Figure 4). The stabilization of foams and emulsions due to the structural-mechanical factor enables to significantly extend the shelf life of these products.

The research into the joint impact of substances with various surface activity rates allowed for emulsion stabilization with a combined emulsifier - protein and lecithin [51], protein and polysaccharide $[34,50]$. In this stabilization, provided a specific correlation of two surfactants, the main stabilizer, though being partly replaced from the drop surface with a more active surfactant, but insufficiently to damage mechanical strength of the shell. These adsorption shells are mobile and easily self-restored. 

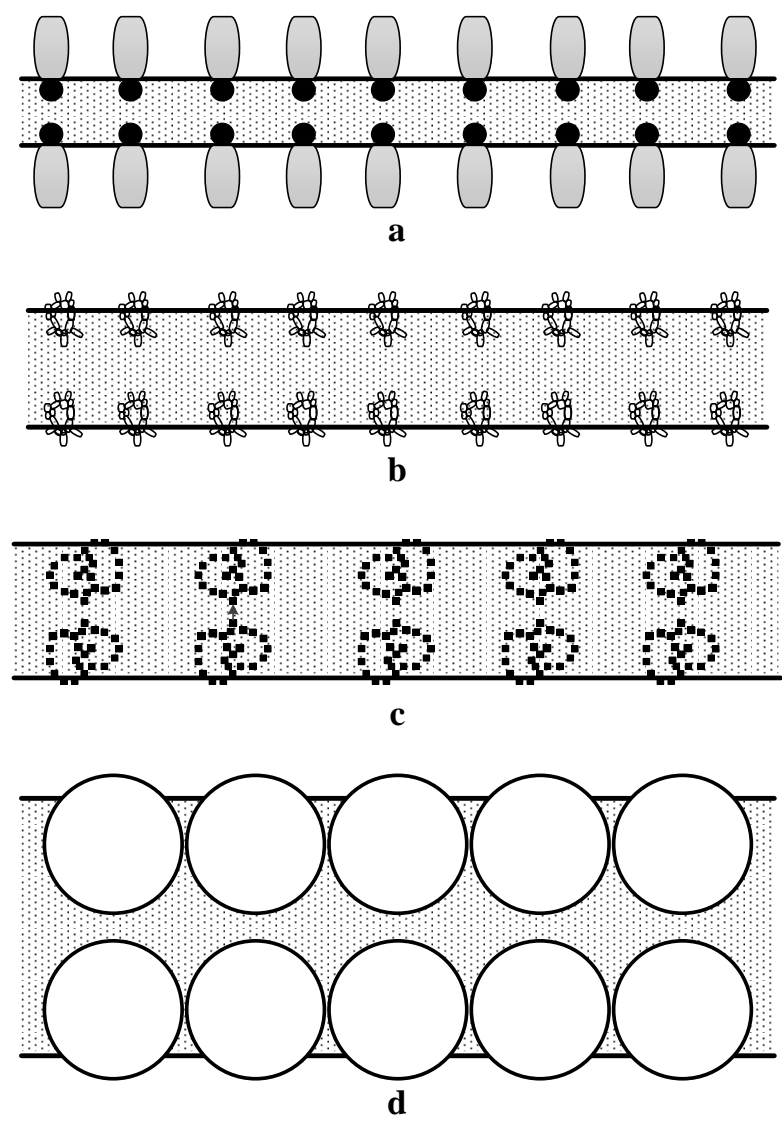

Figure 4. Schematic representation of relative thicknesses of thin films between closely approaching oil droplets stabilized by (a) surfactants, (b) proteins, (c) hydrocolloids (complex protein polysaccharides) and (d) colloidal particles (Pickering stabilization) [49]

Self-restoring emulsion properties are also typical of stabilizers thixotropic solutions, which can create a spatial network in the dispersion medium or form complexes with proteins and stabilize emulsions. The spatial network, on the one hand, binds a stabilizer with an adsorption layer, on the other - with the dispersion medium. The spatial network can be destroyed mechanically and easily restored upon the force loss $[52,53]$. There are four kinds of systems, containing two polymers and a solvent:

1. The solution containing two neutral polymers refers to the segregate systems (i.e. formation of two solutions that do not mix).

2. A neutral polymer and a polyelectrolyte, that mix with each other with no creaming or sedimentation, can form associates due to the hydrogen binding, and during the charge neutralization the system may break into phases that do not mix [54].

3. Like-charged polyelectrolytes, thermodynamically incompatible, refer to segregate systems. 
4. Oppositely charged polyelectrolytes. The electrostatic attraction between the oppositely charged groups leads to the emergence of complexes with rather strong binding, i.e. these systems refer to associative ones. They are widely spread in living systems and are commonly used in practice. Polyelectrolyte complexes are formed owing to the cooperative reactions of oppositely charged functional grouping. Cooperative reaction implies the emergence of each inter-chain salt binding, facilitating the formation of further bonds between polyelectrolyte complex chains, which makes is highly stable [55, 56].

The simplest way of producing polyelectrolyte complexes is mixing the solutions, where one contains anionic, and the other - cationic polyelectrolyte. There are two types of polyelectrolyte complexes - stoichiometrical and non-stoichiometrical. Stoichiometrical complexes are normally water-insoluble and characterized by high hardness and hydrophobicity. Non-stoichiometrical polyelectrolyte complexes are water-soluble as there are chain segments that were not involved in complex formation. The formation of the complexes features considerable viscosity increase, in some cases even gel formation. All these processes are influenced by $\mathrm{pH}$, solution ionic force and other factors [57]. The production of polyelectrolyte complexes of milk proteins and low-etherified pectin on interphase surfaces enables not only to strengthen emulsion, but also to raise destruction resistance under temperature rise [58].

It was found that if the $\mathrm{pH}$ value is above the isoelectric point, proteins and anionic polysaccharides form soluble complexes, while if $\mathrm{pH}$ is below the isoelectric point, the formed complexes are water-insoluble [59, 60]. Thus, provided the conditions of forming soluble polyelectrolyte complexes between proteins and anionic polysaccharides, according to the structural-mechanical stabilization factor theory, it is possible to produce stable foams and emulsions.

Following the data analysis of the indicators, ensuring the stability of dispersion systems, structural mechanical stabilization factor varieties show high performance.

\section{Factors in foam and emulsion stabilization}

Food emulsion stabilization frequently involves the increase of dispersion medium viscosity. It was found that the inclusion of k-carrageenan polysaccharide in aqueous phase at $0.4 \%$ slightly raised the concentrated drop average size (30\% soy oil) in sodium caseinate emulsions [61]. If the k-carrageenan content is below $0.2 \%$ there is fast coagulation of oil drops. Under high polysaccharide concentrations emulsion creaming decreases due to the formation of the mesh structure of flocculating drops. Emulsions viscosity rises along with the increase of the k-carrageenan content. The stability of emulsions, their structure and rheological properties directly relate to the quantity of the polysaccharide added to the aqueous phase.

Sodium caseinate-stabilized emulsions with k-carrageenan feature pseudo-plastic behavior, showing the reverse flocculation of oil drops. Similar properties are typical of whey protein isolate emulsions [62]. It was also identified that if $\mathrm{pH}$ is $<6.0$, and, mainly under low shear rates, the emulsion effective viscosity rose, which stabilized emulsions against creaming. This effect referred to creating oil-droplet bridges due to electrostatic interaction between whey protein isolate and k-carrageenan on the drop surface and formation of a netlike framework.

When studying the impact of k-carrageenan on the bovine-serum-albumin-stabilized (BSA) emulsion properties, it was found [63] that under the aqueous phase $\mathrm{pH}$ of 6.0 and certain polysaccharide limit concentration there emerges the so-called "binding" 
flocculation, which leads to the formation of an oil-drop netlike framework. Provided the above $\mathrm{pH}$ value, experimental data on surface tension under the low ionic force show strong electrostatic BSA and k-carrageenan interaction.

It was established that adding low-molecular surfactants or polysaccharides to a proteincontaining system causes emulsion flocculation and form destruction [64, 65]. To this end, the examination of the visco-elastic properties of sodium caseinate stabilized 1Bromohexadecane-in-water emulsions confirmed [65] that under low xantan gum content, the region of emulsions linear visco-elasticity reduces, which, according to the authors, shows drop flocculation. In other words, the stabilizer acts as a flotation agent, which may be caused by charge neutralization on the surface of dispersed particles or by simultaneous adsorption of polysaccharide on different particles, thus intensifying their flotation. However, the rise of polysaccharide concentration is accompanied by the increase of visco-elastic properties - the elasticity module and complex viscosity values grow. As xantan content rises in the emulsion flow curves, there emerges a Newtonian region in the flow. Therewith, the value of the highest Newtonian viscosity grows along with the rise of the polysaccharide content in the system. That points to the formation of a spatial structure, which hinders the emulsion drops motion, and to the lower flocculation of emulsion drops. When analyzing emulsion relaxation properties it was shown that the higher xantan concentration in the stabilizing mix, the longer relaxation is required [65], which also indicates protection against emulsion drops flocculation when polysaccharide is added. The obtained data are quite comparable with findings in [66].

Studies were carried out on the stability of n-tetradecane aqueous emulsions [67, 68], stabilized by sodium caseinate and non-ionic surfactant Tween-20 (Polyethylene glycol sorbitan monolaurate) at $21{ }^{\circ} \mathrm{C}$. In the emulsions with a stable surfactant content, the replacement of Tween-20 with caseinate leads to higher emulsifying, which, in turn, increases protein content. In addition, under lower caseinate concentrations in emulsions, their rheological parameters gradually change from visco-elastic to Newtonian - non-ionic surfactants Tween-20 weakly interact with proteins and reduce sodium caseinate emulsion viscosity. This is determined by the ability of the non-ionic surfactant, in case of adsorption, to replace protein macromolecules from the drop surface.

It was noted in [69] that despite new studies in the rheology of emulsions and interface layers, the data related to the correlation between the rheological properties of protein adsorption layers and protein-surfactant mixes and emulsion stability based on these systems are insufficient due to the missing indicator or quantitative ration between rheological interface properties and emulsion stability. It is noted that without the data on the ingredients, structure of sodium caseinate-surfactant associates and mixed interface adsorption layers it is impossible to identify the emulsion stabilization mechanism.

Thus, the joint use of proteins and polysaccharides or proteins and surfactants enables to regulate the stability of emulsions and foams. However, the mechanisms ensuring the stability (as shown in analyzed literature) may vary even in the systems with identical surfactants, but with different proportions. The situation becomes more complicated provided a polyphase system.

\section{The perception and stabilization of foam emulsions}

The availability and kind of oil differently influence the process of foaming and foam stability, which depends on the oil content, fat globule size and its aggregate condition [67, 70]. The production of foam emulsion systems using hard oils improves foaming ability and foam stability. This is the way to stabilize ice cream structure [71]. This process is related to foam stabilization due to adhesion of solid fat particles on air bubbles [72] (Figure 5). 


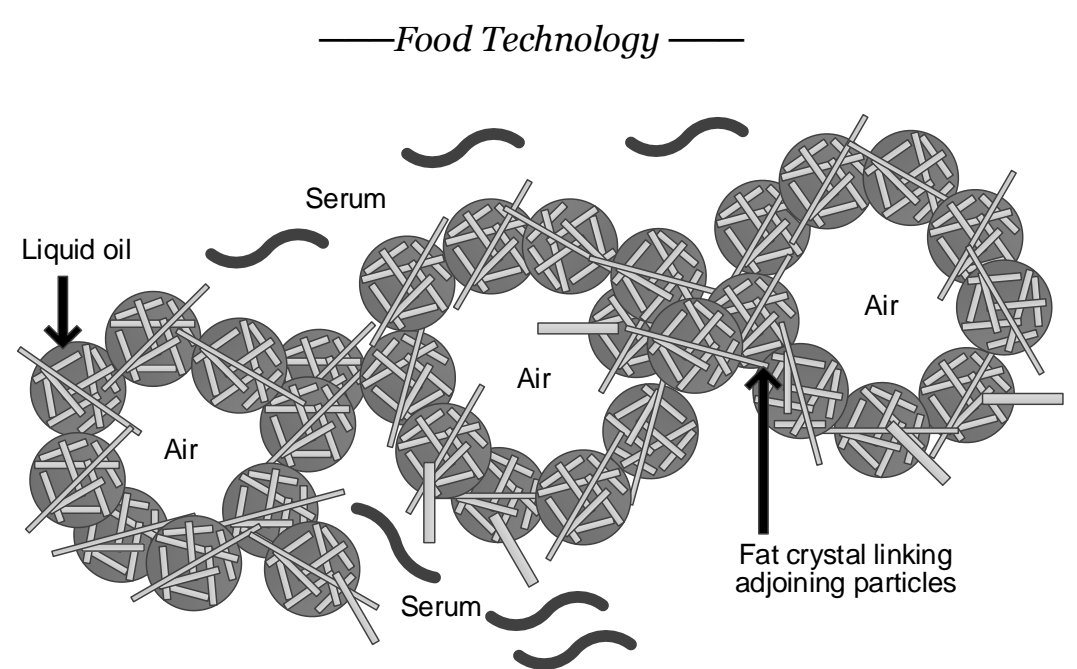

Figure 5. Adhesion of fat particles on air bubbles as a factor of foam emulsion stabilization [73]

The addition of liquid oils to foamy protein-based systems leads to lower foaming capacity and foam stability, which is related to the foam destruction and is in its ability to intensively replace protein from phase boundaries and entail the rupture of interface adsorption layers. Vice versa, the addition of hard oils raises the foaming capacity and mechanical strength of foam emulsion systems [74]. The addition of liquid oils is an effective antifoam [75], which is used in antifoaming technologies. The antifoam mechanism is in the fact that due to the adhesion of oil drops on air bubbles they, depending on the size of the surface tension, either spread on the surface of the bubble, or form a fat bridge between two adjacent bubbles (foam is destroyed anyway) Figure 6.

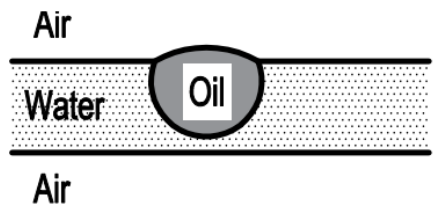

$\mathbf{a}$

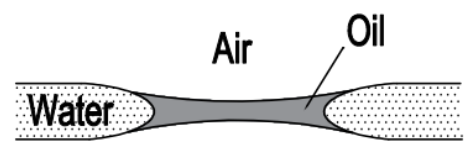

Air

C

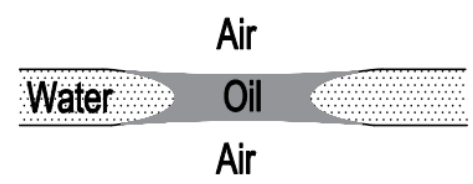

b

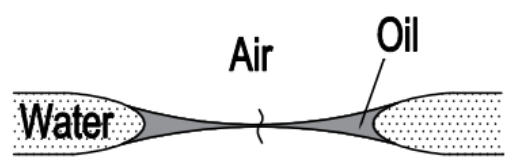

Film rupture

d

Figure 6. Schematic presentation Bridging-stretching mechanism of foam film rupture. (a-b) Bridging of the foam film surfaces by antifoam globule leads to an oil bridge with nonbalanced capillary pressures at the oil-water and air-water interfaces.

(c-d) The bridge stretches with time until a thin, unstable oil film is formed in the bridge center.

The rupture of this oil film leads to destruction of the entire foam lamella [76]. 
However, in case of forming a fat bridge the destruction becomes more effective. To describe these processes a theoretical model was developed. Therewith, it involved Dupre equation and the equation of defining Harkinson spreading parameter, which the authors call the input and the spread ratios, respectively. This model describes the foam destruction process. It is noted that provided an input barrier, at the bubble interface foam destruction becomes less effective, which requires inputting non-spherical hydrophobic particles into oil $[76,77]$. The input barrier may be created by colloidal surfactants, proteins. If there is an adsorption layer on fat particles and air bubbles, the stability of systems is determined by the behavior of pseudo-emulsion film, surface, interfacial tension and film tension, which create the Neumann's triangle [78].

When studying the impact of oil mixes with different content of liquid triglycerides, it was found that the higher the liquid triglycerides content is, the lower the volume of foam is. That is the result of the oil spreading on the air/water interface [79] Figure 7.

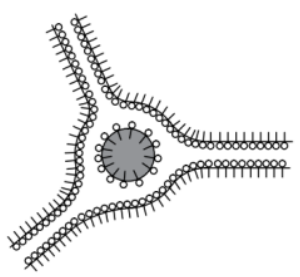

a

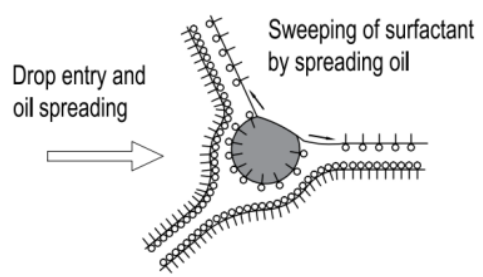

b

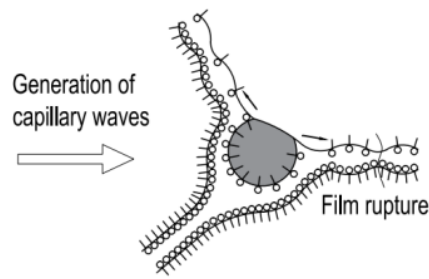

c

Figure 7. Schematic presentation of the "spreading-wave generation" mechanism, (a, b) Entry of an oil drop in the region of the Plateau channel leads to oil spreading on the surfaces of the neighboring foam films $(b, c)$.

The higher the fat phase content in foam emulsion systems is, the higher the air dispersion general volume becomes, which indirectly points to the fat globules involvement in the air bubble stabilization [80]. There is also a shift of the foaming maximum towards a later whipping stage, which is, probably, related to the increase in the system viscosity. The impact of other factors on the air dispersion volume appears related to the fat dispersion destabilization. Lower destabilization and higher whipping temperature reduce foam volume. Higher destabilization of emulsions due to longer storage of cooled fat-containing emulsion products and higher acidity result in higher foam volume [81].

The air of foam emulsion structured products undergoes considerable changes while being whipped. These changes are cause by mechanical impact of mixing. The average diameter of air bubbles, which is $100-150 \mu \mathrm{m}$ during the first five minutes, gradually reduces to $50 \ldots 70 \mu \mathrm{m}$ by about the mid of the process and further it increases by $20 \mu \mathrm{m}$ on average till foam destruction [81].

When emulsion products are whipped, individual fat particles aggregate. This process of fat particles aggregation is both on the water/air interface and thoughout the volume of the systems. The initial stage of aggregation is the involvement of hydrophobic fat globules interfaces (flotation). The fat particles aggregation in the volume phase is not normally caused by simple collisions of single particles, but when air bubbles are actively introduced and then used to float fat globules [72]. 
The conditions of dispersed particles flotation include the creation a non-zero contact angle of the continuous phase and a dispersed particle, low viscosity of dispersion medium, no "protective barrier", which can be formed by high-molecular compounds [82, 83], significant shift rates (a turbulent flow), which raise the probability of air bubbles collision with dispersed particles $[84,85]$. Higher hydrophobization (destabilization) of the fat phase raises the contact angle.

The process of fat particles aggregation in the aqueous phase comprises two successive stages: flocculation of fat globules with preserved, though somewhat changed shells and the aggregation of glyceride nuclei of fat globules to form emulsion gels [86, 87]. The aggregation of fat particles and forming emulsions gels might occur due to building the binding hydrophobic or salt bridges between proteins on different fat particles [88] or due to the hydrophobic binding between fat crystals or liquid oil [89, 90]. The value of the structural-mechanic barrier to be overcome by the fat globules aggregation is determined by the degree of shell native structure destruction during the whipping process or another mechanical impact. The first stage of the fat bubbles aggregation at the water/air interface is their flotation by air bubbles. The main pre-condition of this process is the hydrophobicity of the fat particles surface. The hydropobization of fat globules surfaces is ongoing throughout the emulsion production, during products preparation for whipping and while whipping; it is related to the shell loss of the most hydrophilic elements. As they are removed, the shell surface (fat globule surface) grows hydrophobic. Consequently, the shell surface becomes mosaic. Hydrophobic and hydrophilic regions are unstable, and they differently interact with the molecules of the aqueous medium $[81,86]$. Accordingly, emulsion whipping process depends on the original size of the fat globules and the enlargement of fat particles while whipping [91, 92].

The foaming capacity and stability of foams in foam emulsion systems depends on the functional process properties of surfactants, namely, on the interface activities between surfactants and proteins, carbohydrates, and fats, which form rheological properties of foodstuffs $[93,94]$. Depending on the specifications and texture characteristics it is necessary to regulate spatial distribution of fat particles in the aerated product, which requires different process solutions and recipes. For instance, in creams fat particles need to be distributed on the surface of air bubbles (Figure 8, a) thus providing plastic texture properties. In oil, chocolate and nut sponge cakes and aerated nut semi-finished products they are to be distributed throughout these products (Figure 8, b), since during the thermal treatment fat particles on the bubble surface will destroy and reduce the volume of the foam.

Surfactants in foam emulsion systems can destabilize emulsion, caused by mechanical impact, and lead to fat agglomeration. While whipping, agglomerates form a strong structure around air bubbles and among them, thus stabilizing the foam. To achieve required indicators of foaming capacity, foam stability and finished product texture, the functional and process properties of surfactants are to be considered, as they ensure destabilization and agglomeration of fat particles in foam emulsion systems. The fat phase agglomeration raises foaming capacity and foam stability in foam emulsion systems, though the mechanisms underlying the foaming capacity rise have not been fully clarified [95, 96].

It was found in [97] that the entry of saturated mono-glycerides in the emulsion fat phase enables to form foam emulsion systems with high foaming capacity, high air phase dispersion, dense texture, whereas the use of unsaturated mono-glycerides leads to forming soft foam emulsion systems with few large air bubbles, which sediment faster while being stored. 


\section{- Food Technology —}

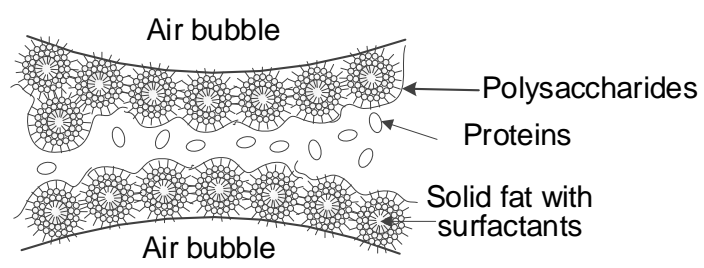

a

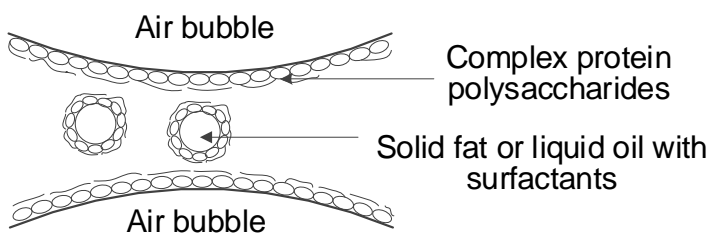

b

Figure 8. The diagram of foam emulsions with fat particles on air bubbles (a) and throughout the system (b)

The studies in $[98,99]$ made it evident that during the reconstitution and whipping of fat-containing mix powders, surfactants play an important part in destabilizing the emulsion, while protein is necessary to create the initial emulsion stability. Reconstituted whipped systems are mainly stabilized providing crystal fat at water/air interface [99, 100]. It was proven in [98] that a part of the fat in spray-dried mix powers is overcooled. During the reconstitution of these mix powders at low temperatures by adding water, there are significant changes that determine whipping properties and foam structure. The emulsion becomes unstable due to the rapid recrystallization of overcooled fat [101, 102]. The emulsion destabilization promotes protein desorption from the water-oil surface [103, 104].

Therefore, foam emulsion systems are stabilized due to surfactant properties at various interfaces. It is necessary to consider the interaction of different surfactants in foam emulsions. The sequence of dispersion phase production in foam emulsions specifies their spatial location and different texture properties. Thus, it becomes possible to make products with different textures but identical system ingredients.

\section{Interface protein and low molecular surfactant interactions}

Interface protein and low molecular surfactant interactions at the water-fat interface play an important role for the emulsion stability, destabilization level control, and for the formation of foam emulsion system texture. Surfactants influence fat crystallization, preventing their recrystallization, which leads to defects in fat-based foodstuffs $[95,106]$.

Functional and process properties of food surfactants are determined by their chemical composition, which is due to the hydrophilic and hydrophobic properties of molecules [107, 108]. The surfactants that have distinct hydrophilic properties, in particular, anionic surfactants or non-ionic ones with high hydrophilic-lipophilic balance, can disperse in water $[109,110]$. These surfactants are adsorbed on the water-oil interface or interact on other phase interfaces with other foodstuff components, e.g. with proteins [111, 112].

In the systems containing several surfactants three kinds of adsorption are singled out: competitive, associative and layered. Schematically, the adsorption kinds are shown in Figure 9 . 

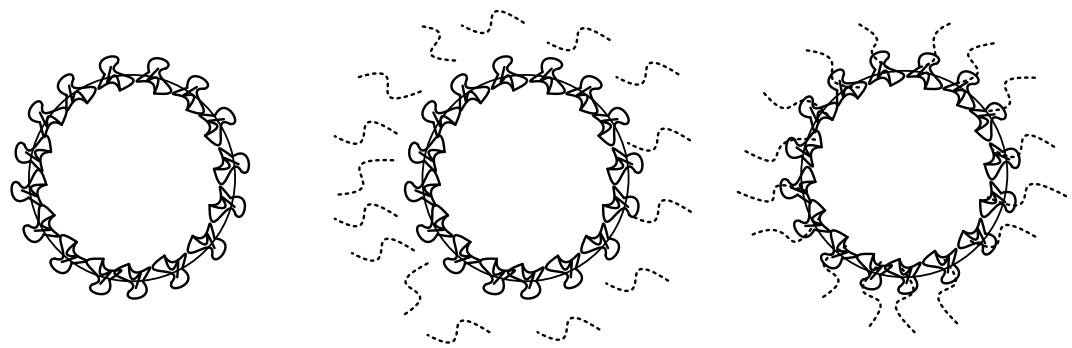

$\mathbb{S}$ WPI $\cdots$ beet pectin $\quad$ WPI beet pectin conjugate

\section{a-Associative [114]}
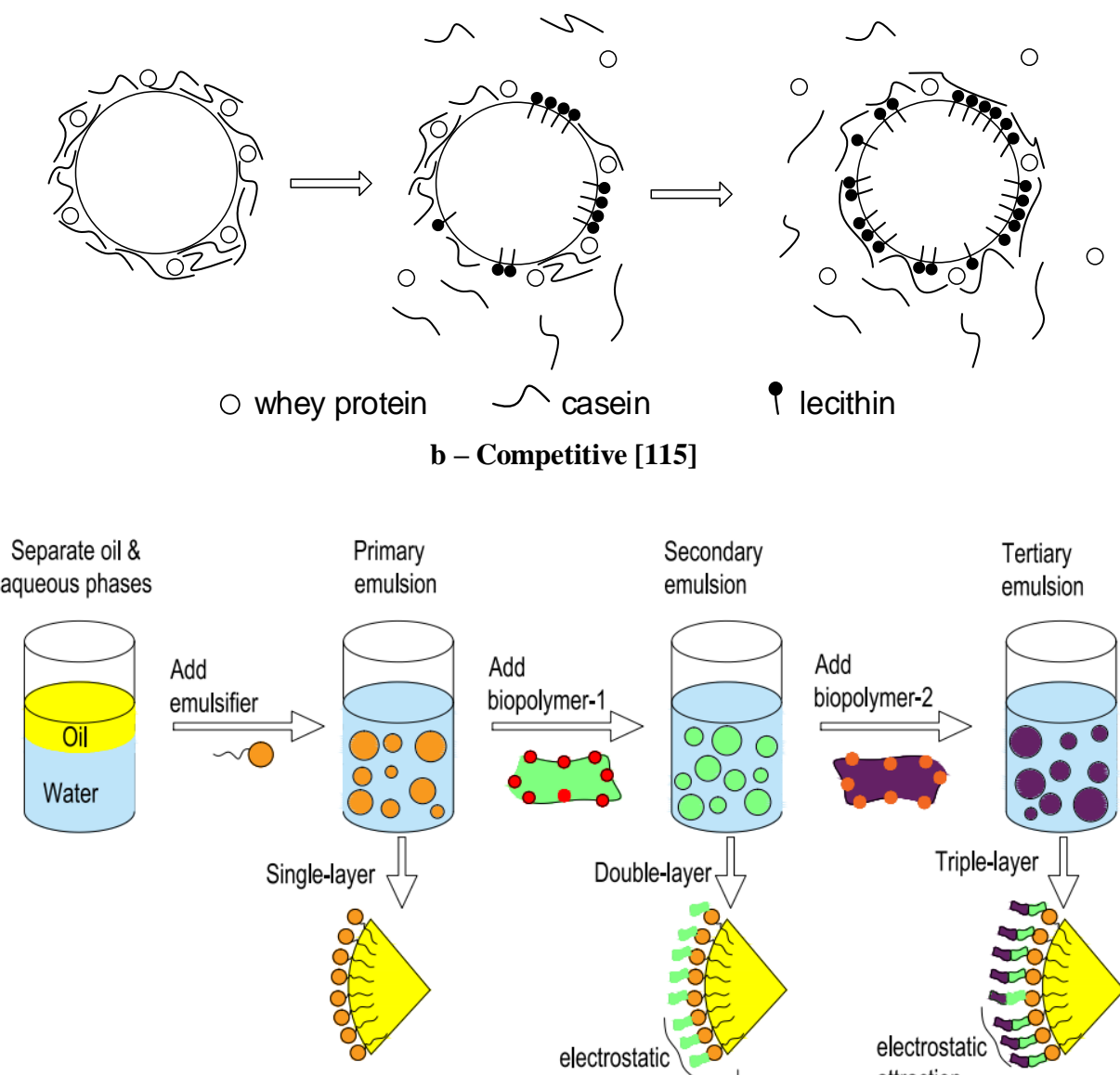

Secondary

Tertiary

aqueous phases

emulsion

emulsion
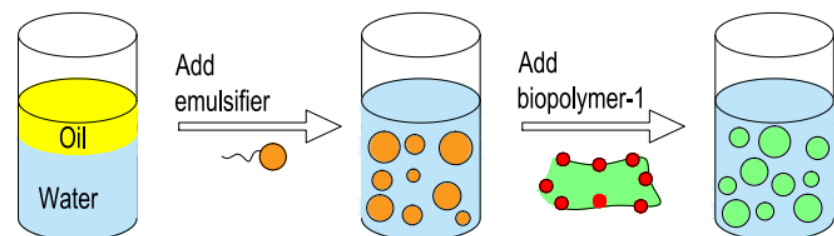

Add

biopolymer-2
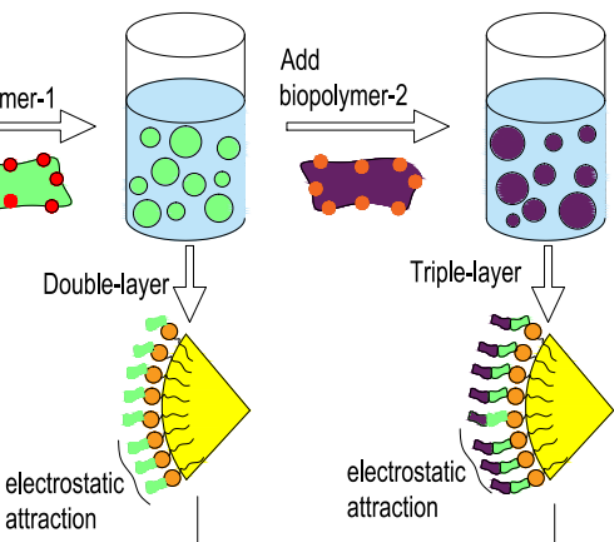

electrostatic attraction

Repeat coating

c-Layered [116]

Figure 9. The diagram of adsorption in the systems with several surfactants:

a-Associative; $\mathbf{b}$ - Competitive; $\mathbf{c}$ - Layered 
Dairy and many other products, containing proteins, interface adsorption layers are a mix of proteins and surfactants. The actual composition of interface adsorption layers depends on the chemical structure and relative concentrations of proteins and surfactants. During the adsorption of the chaotic protein, e.g. $\beta$-casein, rather thick interface adsorption layers with long hydrophilic ends are formed. They exude at phase interfaces, while the molecules of $\beta$-lactoglobulin are densely located near the phase interface, forming thinner interface adsorption layers [113]. The availability of surfactants impacts adsorbed proteins, in many cases replacing them from the phase interfaces, which promotes protein foaming in emulsion systems.

Non-ionic surfactants with high hydrophilic-lipophilic balance most effectively replace proteins from the interface at $15-25^{\circ} \mathrm{C}$ compared to non-ionic surfactants with low hydrophilic-lipophilic balance, for example, with mono-glycerides [117, 118]. The impact on the adsorbed protein depends on the surfactant concentration. Providing the concentration is low, the surfactant has nearly no effect on the level of protein, adsorbed on the surface, whereas higher concentration enables almost total replacement of protein from the interface, which significantly destabilizes the emulsion.

Lipophilic surfactants are less effective in replacing the protein from the phase interface. The combined use of lipophilic and hydrophilic surfactants leads to the synergy in the protein replacement $[117,118]$.

The effectiveness of protein replacement from the phase interface with a specific surfactant is considerably dependent on the closeness of the surfactant to the phase interface. For many lipid surfactants this process depends on temperature. Low-polarity surfactants (mono-glycerides), in small quantities, at high temperature (above $70^{\circ} \mathrm{C}$ ) increase the content of protein, adsorbed on the surface. Protein adsorption decrease occurs at higher concentrations. Diglycerides (E471) do not affect the adsorption or replacement of proteins [93]. At $10-40{ }^{\circ} \mathrm{C}$ saturated and unsaturated mono-glycerides (E471) decrease the interfacial tension more intensively than protein [119]. This is due to the formation of mixed interface surfactant-protein adsorption layers. Provided the temperature is below $10{ }^{\circ} \mathrm{C}$, there appears a distinction between saturated and unsaturated mono-glycerides: saturated ones, unlike the unsaturated, determine significant decrease in the interfacial tension. The difference in the impact of saturated and unsaturated mono-glycerides on the interfacial tension at low temperatures is explained by the surfactant crystallization - saturated mono-glycerides feature higher Krafft point temperatures than the unsaturated ones.

Surfactants with stronger hydrophobic properties (saturated mono- and diglycerides, lecithin and polysorbates) more intensively reduce the interfacial tension owing to their hydrophobicity. Furthermore, their impact on the interfacial tension is less temperature dependent. A more significant decrease of the surface tension is determined by higher adsorption of the surfactant on the phase interface, thus replacing more protein. However, in food emulsions with high protein concentrations, its total replacement is not observed [120, 121].

Similarly to protein and surfactant interaction in simple emulsions, complex food emulsions involve interaction of different proteins. The proteins that are more surface-active may replace less surface-active proteins, for instance, $\beta$-casein is more likely to replace $\alpha$ casein than vice versa. It was also proven that casein is added into a gelatin-stabilized emulsion, the added protein can replace gelatin $[122,123]$.

Under certain circumstances, the fat phase destabilization, important for foam emulsion systems (creams, ice cream etc.), may be achieved by adding differently polarized surfactants. The destabilization includes several physical changes, occurring in the emulsion, in particular, partial desorption of the interface protein and fat phase crystallization. Both 
processes decrease emulsion stability during a mechanical impact. It is known that fat crystallization is required to achieve partial coalescence [124]. The addition of different surfactants can affect the degree of the fat crystallization and the shape of the created fat crystals. With water available, saturated and unsaturated surfactants promote the formation of different fat crystals. In model systems as well as in food foam emulsion ones the use of unsaturated mono-glycerides leads to forming large, multi-faceted fat crystals, while saturated mono-glycerides encourage forming smaller but more evenly structured fat crystals $[125,126]$.

During the emulsion whipping, protein is partially desorbed. For the beginning of fat globules flocculation protein replacement from the fat globule surface is not required [127]. Thus, for the partial destabilization of the emulsion, which is necessary to produce foam emulsion systems, the impact of surfactants on rheological properties of interface adsorption layers may be more important than their ability to replace protein. It was found that unsaturated mono-glycerides facilitate destabilization more than the unsaturated ones [119]. The control of the interaction among proteins, surfactants and fat particles on the surface of the water-air interface in foam emulsion systems can be considered as the process of air bubbles stabilization [128, 129].

Therefore, the process of forming and stabilizing foam emulsion systems is influenced by a number of factors, which eventually determine not only the stability of these systems but also their rheological properties [130]. However, rheological properties of food foam emulsion systems have been studied insufficiently, and the rheological behavior of these dispersion systems are frequently characterized qualitatively. Despite the fact that the properties of the interacting phases and components of foam emulsion systems during their formation and stabilization are essential factors for their diversity, their relation to the foaming capacity and foam stability has not been fully identified, which is determined by a wide composition of food dispersion systems and the conditions of their production.

The analysis of the above information enables to state controversial as to the stabilization of foam emulsion systems. Obviously, the stability of foam emulsion systems is achieved by raising the viscosity of dispersion medium - adding a stabilizer, higher content of the dispersion phase, ensuring conditions for fat particles agglomeration and forming a three-dimensional grid, the formation of strong interface adsorption layers on the surface of dispersion particles. As to the controversial data, it is necessary to specify the conditions and the need of fat particles flotation by regulating their contact, which, in turn, leads to the need of identifying the conditions of forming interface adsorption layers using proteins, surfactants or their mixes. To ensure flotation, it is necessary to identify the rational dispersion capacity of fat particles. It becomes evident that the key role belongs to the interface adsorption layer formation and the identification of regularities in their control, as well as the mechanisms, underlying their formation and destruction. It is clearly specified what conditions are required for the fat particles to agglomerate, float and adhere to air bubbles and the conditions, under which fat particles can provide process stability to the systems with a polyphaser dispersed structure.

The study allowed us to specify the concentrations of proteins and surfactants as well as the parameters of homogenization and whipping under which there emerge processes of emulsion destabilization, fat particle agglomeration and flotation to produce a foam emulsion system [131]. The role of proteins and surfactants was identified and NaCMC in resistance to fat particle flotation and make the structure of the aerated nut semi-finished product [132]. The process flow parameters and the content of proteins and surfactants in dry fat mixes to produce a foam emulsion system based on them [133]. 
Thus, interface adsorption layers play an essential role in stabilizing foams, emulsions and dispersion polyphaser systems.

\section{The role of interface adsorption layers in process stability of food heterogeneous systems}

The structural mechanical barrier is expressed in inhibiting coalescence and is among universal factors of dispersion system stabilization owing to its high viscosity, elasticity and mechanical strength of the interface adsorption layers. The best known interface adsorption layers are based on proteins; they can form quasi-crystal or gel-like structures. The data on the protein adsorption show $[34,134]$ that the effective stabilization is ensured only provided protein on the phase interface. This ensures the formation of a monomolecular layer. These interface adsorption layers determine dispersion system stability. Structured interface adsorption layers of proteins form 10-100 nm thick layers, which are sometimes are considered as a separate phase, where the protein content in this interface adsorption layer may be $20 \ldots 40 \%[34,35]$. The role of the structural mechanical barrier in the stability of direct emulsions, stabilized by high molecular substances, was proven [135, 136].

To enforce the structural mechanical stabilization factor it is important to:

- provide decrease of the surplus free energy at the phase interface [137, 138];

- ensure the Hamaker constant, especially on the outer part of the stabilizing layer, which lowers energy and the force of dispersion particles interaction [139, 140];

- provide high shear stress, elasticity module, the viscosity of an interface adsorption layer (elastoplastic body) [141, 142];

- confirm the need to overcome a high activation barrier to destroy the interface adsorption layer (according to Zhurkov's theory) [136].

The structural mechanical barrier includes thermodynamic (elasticity modules) and kinetic (viscosity) factors, which may guarantee stability of dispersion systems in case of drop interaction [143, 144]. The stabilization of dispersion systems with high molecular substances is usually considered within the steric stabilization model [145, 146]. The steric stabilization can be regarded as a special case of the structural mechanical barrier effect [147].

The study of the structural mechanical barrier role in the stability of foams and emulsions includes the assessment of rheological parameters and the structure of stabilizing layers as well as the study of the peculiarities of losing aggregate stability of bubbles and drops when interacting with each other [34].

Today it is possible to consider a new science - rheology of interface adsorption layers, which emerged at the boundary of biological disciplines (molecular biology, biophysics and cytology), physical chemistry, physical-chemical mechanics of dispersion systems and rheology [148].

To describe the kinetics of pattern structuring in the interface adsorption layers the study in [148] offers a quantitative method, based on the parameter of structure strength growth in the interface layers of polyelectrolytes and their mixes with surfactants. The time of reaching the permanent shear stress $\mathrm{P}_{\mathrm{s}}$ (maximum number of contacts) in the layer and the balanced surface tension is measured in hours.

The process of forming adsorption layers by proteins is divided into three stages. At the first stage there is diffusion to the phase interface, at the second - a contact with a phase, resulting in destroying the force balance, stabilizing the globule, and, accordingly, there occur conformation changes, i.e. orientation processes, at the third stage, there is a process of saturating the surface layer and the reduction of surface energy [149]. 
Adsorbed molecules hamper further adsorption. Depending on the redistribution of components among phases and on the king of protein there are two types of interface adsorption layers: gel-like and quasi-crystal [147, 150]. During the multilayer adsorption the protein-oil binding is replaced by the protein-protein binding, and this adsorption becomes reverse $[151,152]$. It is known that proteins with flexible chains (beta-casein) are more surface active that globular proteins (lysozyme, beta-lactoglobulin, alpha-casein) or hard rodlike proteins, which becomes, inter alia, evident when studying the time of forming adsorption layers.

The rheological properties of the interface adsorption layers of high molecular surfactants on the flexible phase boundaries have been studied thoroughly [153, 154]. It was shown that the adsorption layers are characterized by the shear stress, modules of plasticity and elasticity.

As the concentration of the high molecular surfactant in the aqueous solution increases, it is possible to observe the transition from the liquid state of the layer with a low quantity of contacts, which shows Newtonian behavior, to the solid-like, strong low-defect elastoplastic structures.

Significant scope of accumulated data on interface adsorption layers rheological properties enabled to summarize the information and develop models, underlying the interface adsorption layer formation. For example, the models of gel-like and quasi-crystal interface adsorption layers correspond to the structures with coagulation and crystalcondensate contacts [147, 151]. The models of interface adsorption layers formation were developed and their quantification was carried out in the conditions of the combined use of proteins and polysaccharides $[155,156]$, the combined use of proteins and low-molecular surfactants [159], and the combined use of several proteins [160, 161]. However, there is scarce data on the properties of the interface adsorption layers, formed by proteins and solids [162]. However, the developed models refer to foams or emulsions. As to the models of dispersion system stabilization with two or more phases, these studies are limited, and discuss only foam emulsion systems $[79,90]$ and creams $[73,163]$. These models are based on the principle of surface and interfacial tension and their values, which enables to substantiate the principles of stabilization. Nevertheless, following the values of the surface and interfacial tension it is impossible to explain the processes, occurring when whipping emulsions, and, probably, it is necessary to consider rheological properties of interface adsorption layers [79]. The stability of foams and emulsions greatly depends on the properties of interface adsorption layers [137, 164]. The knowledge limited by the value of surface or interfacial tension is insufficient to understand and forecast their behavior; rheological properties are more useful and informative to assess the behavior of these systems. Rheological properties of interface adsorption layers correlate to the rheological properties of foams [165] and the stability of foams and emulsions [166] as well as theoretical models [167]. Using the rheological properties of interface adsorption layers, theoretical models were developed on the foodstuff patterns with steric-stabilized polyphase dispersion structures [132], foam stabilization with fat particles [131] and their combination [133].

The analysis of literature in the field has confirmed the need to use rheological methods to do research into interface adsorption layers.

\section{Methods of studying rheological properties of interface adsorption layers}

The overview papers $[156,158]$ provide the list and features of rheological methods of studying interface adsorption layers. In addition to the torsion viscosimeter with various disk shapes, other devices are applied, but it is remarked that the torsion viscosimeter is the most 
universal tool in researching interface adsorption layers with proteins. It was found that depending on the selected theoretical model of interface adsorption layers, different methods are used to study rheological properties of interface adsorption layers [157].

Surface rheological properties measurement results, obtained using the torsion surface viscosimeter [34], brought to the conclusion that there is perfect analogy of surface and volume rheology provided that measurements of surface layer rheological properties are carried out on flat faces and liquid phase interfaces. Thus, the mathematical tools, developed to describe rheological properties of three-dimensional systems, may be applied to studying rheological properties of interface adsorption layers.

To describe the interface adsorption layer behavior, it is possible to use methods with different mechanical impact on the interface adsorption layer (under permanent deformation, continuous stress, waved stress) and thus it is possible to specify such indicators as the yield shear stress [34, 169], viscosity [170], modules of plasticity and elasticity [171, 172]. To assess emulsion stability the Boussinesq number as the correlation of the interface adsorption layer viscosity to the medium viscosity [168]. In case the Boussinesq number is considerably higher than one, the system is stable, and vice versa - if it is below one - stability is low. A dilatational elasticity module is used as the ability of interface adsorption layers to resist external forces and restore interface adsorption layers to the original state after the external force termination [173, 174]. The viscosity and dilatational elasticity module are used in the systems with low protein content (up to $0.5 \%$ ) or in the systems, containing low molecular substances. For the systems with high protein content (over $0.5 \%$ ) in the systems, containing proteins and polysaccharides the yield shear stress of interface adsorption layers is found, as well as the elasticity module [33, 34].

Considering the known data and interface adsorption layer models, it is necessary to analyze the main approaches to regulating rheological properties of protein interface adsorption layers, using low molecular surfactants and polysaccharides. As mentioned above, surfactants can either raise or lower the stability of emulsions and foams.

\section{Regulation of rheological properties of interface adsorption layers}

The research into the rheological properties of gelatin interface adsorption layers showed that the layers feature visco-elastic properties [178]. A model of an interface multilayer pattern was suggested. According to it, the gelatin adsorption layer at the waterair boundary consists of one irreversibly adsorbed monomolecular layer and several reversible adsorbed secondary layers.

The yield shear stress of interface adsorption layers rises along with the protein content rise in the system, reaching the maximum, typical of gelatin для желатини, ovalbumin and casein [34]. It is due to the fact that the maximum shear stress corresponds to the monomolecular layer and strongest binding (cohesion force) of protein-protein. The maximum yield shear stress of protein interface adsorption layers meets all requirements to their coagulation, i.e. under the environment $\mathrm{pH}$ value that corresponds to the protein isoelectric point, ovalbumin thermal coagulation temperature $\left(55^{\circ} \mathrm{C}\right)$ the strength of the interface adsorption layer at the water-air interface rises 10 times. The regulation of the solution ionic force and the addition of substances, suppressing the formation of hydrogen bonds, enabled to define that bond formation in interface adsorption layers is due to the hydrogen, electrostatic and hydrophobic interactions. It was found out that regardless of the protein in the yield shear stress of interface adsorption layers at the phase interface with a non-polar solvent is 6-10 times higher compared to the interface adsorption layers at the 
phase interface with air. Thus, this opens a way to regulate the yield shear stress of protein interface adsorption layers either with process factors or with addition of substances [34].

The formation of protein-polysaccharide complexes is widely used in dispersion system stabilization [179, 180]. Therewith, electrostatic or chelate coordination compound is used (formation of salt bridges between proteins and polysaccharides [181]. These complexes are characterized by quite a strong binding. Polyelectrolyte complexes are created as a result of cooperative reactions of uniting oppositely charged functional groups. The cooperative nature of reactions implies the emergence of each inter-chain salt bond, facilitating the formation of other bonds between chains of the polyelectrolyte complex, which makes it highly stable. There are two types of polyelectrolyte complexes - stoichiometrical and nonstoichiometrical $[182,183]$. Stoichiometrical complexes are normally not water-soluble and feature high hardness and hydrophobic level. Non-stoichiometrical polyelectrolyte complexes are water-soluble, which is determined by the presence of chain segments, which were not involved in complex formation $[55,56]$. Being formed, these complexes have high viscosity, in some cases gels are formed, which is influenced by the $\mathrm{pH}$ value, solution ionic force and other factors. The complexes can be formed throughout the volume and further adsorbed, or be built directly at the phase interface [58, 184].

The rheological parameters of interface layers, e.g. their viscosity, elasticity module, and shear stress can be controlled, using surfactant mixes. The strength of mixed interface adsorption layers in the considered systems is always higher than in the conditions, when proteins and surfactants are taken separately, which is determined by the formation of additional hydrogen and hydrophobic bonds between polar groups of both surfactants [142, 144].

The best and systematically known surface properties of protein-surfactants binary systems, as well as their role in forming the structure and ensuring the stability of colloidal systems are those of emulsions or foam. At the same time a special focus is on searching a possible synergetic interaction of proteins and surfactants. The combination of hydrophilic and hydrophobic segments enables the protein to form complexes with ionic and non-ionic surfactants, which is due to different physical-chemical mechanisms. In particular, owing to the electrostatic attraction between oppositely charged functional groups of ionic surfactants and proteins, or owing to the interaction between hydrophobic spots on the protein surface and non-ionic surfactants $[165,174]$. Depending on the concentration, surfactants can interact with protein as individual molecules or as micelle-like aggregates. However, joining the protein, molecules of the surfactants can either stabilize or destabilize the protein structure, while acceleration or inhibiting self-association of protein molecules depending on the type of surfactants (hydrophilic-lipophilic balance, availability of charge), its concentration and environmental conditions (temperature, $\mathrm{pH}$, ionic force) $[185,186]$.

It was established that the addition of phospholipids results in the protein interface layers losing their hardness [187], lower shear stress value [188, 189]. On the other hand, it is possible to strengthen interface layers by forming at the phase interface of inter-polymer associates, using gelatin and water-soluble surfactants (with a high hydrophilic-lipophilic balance) [189] as well as oil-soluble surfactants (with a low hydrophilic-lipophilic balance) [190].

It was stated that proteins, being adsorbed on the fat phase surface, form separate sites covered with protein [191, 192]. At low concentration of surfactants, mixed interface adsorption layers are formed. They comprise adsorbed surfactants and proteins. Surfactants can be adsorbed, being built in between the hydrophobic parts of protein molecules. That explains low correlation of surfactants: a protein does not entail protein desorption. Moreover, low concentrations of mono-glycerides can intensify protein adsorption at phase 
interfaces. Adsorbed surfactants create a rather high surface pressure, interface adsorption layers aggregate, which leads to protein layer thickening. Then the regions of interface adsorption layers are finally removed into the aqueous phase as protein aggregates [193].

Rheological properties of emulsions, containing $\beta$-lactoglobulin and anionic surfactants sodium dodecylbenzenesulfonate (SDS) $\left(\right.$ at $\left.30^{\circ} \mathrm{C}\right)$, are defined by the molar surfactantprotein ratio [194]. A ratio, which enables emulsion elasticity modules to reach maximum values, was found. At the low and high SDS concentration the boundary of emulsion fluidity decreases compared to protein emulsions without surfactants. The results are explained by the specifics of the associated surfactant structures and the interactions between protein and SDS at the phase interface. The addition of SDS to sodium caseinate emulsions [195] raises the stability and viscosity of emulsions, which is explained by binding SDS with protein throughout the aqueous phase and by forming layers with surfactant complexes. The milk protein and iota-carrageenan correlation, under which the shear stress of the interface adsorption layers at the water-air and water-oil phases interface increases, was found [196]. Further, the sodium caseinate and k-carrageenan correlation was identified, too [133]. In both cases the increase of the maximum shear stress of interface adsorption layers is due to the formation of milk protein-carrageenans complexes.

Combined availability of a certain quantitative ration of proteins and surfactants can lead to the formation of mixed adsorption layers or to the competitive replacement of a less surface active component from the adsorption layer [67, 197].

There may emerge thermodynamic incompatibility between proteins and surfactants when exceeding the critical micelle concentration at the phase interface, thus allowing for replacement of one component with another $[198,199]$. In addition, two more mechanisms were suggested to replace proteins from the surfactants phase interface [200]. The first is the mechanism of solubilization meaning the increase of the protein water solubility as a result of forming a more hydrophilic protein-surfactant complex and adding water-soluble surfactants; the other is the replacement mechanism, under which, the surfactant is stronger bound to the surface of the phase interface compared to protein (or a protein-surfactant complex) and replaces the latter.

The stability of foams, based on protein-surfactant mixes, depends on the kind of phase interface of proteins and surfactants under competitive or associative adsorption [201,202]. In the first case, the protein interface adsorption layer is destroyed (i.e. foam stability falls), while in the other case rheological properties of interface adsorption layers strengthen (foam stability rises). For instance, the addition of Tween 20 led to the destruction of foams based on $\beta$-lactoglobulin and $\alpha$-lactoalbumin [203].

The addition of non-ionic surfactants (e.g. Tween-80) to protein aqueous solutions leads to the weak interaction among components [66, 204]. The formation of complexes between bovine serum albumin (BSA) and Tween-80, is due to hydrogen bonds [205]. It was marked that the surface activity of the created complexes, is nearly 5 times higher than protein surface activity and twice as high as the Tween- 80 surface activity.

The interaction between proteins was considered: $\beta$-casein, $\beta$-lactoglobulin, BSA, human serum albumin (HSA) and ionic and non-ionic surfactants throughout the aqueous phase [186]. The models of protein-ionic surfactant complexes were offered. They are formed under low concentrations of surfactants, and under electrostatic interaction between the protein and surfactants, resulting in a hydrophobic complex (associate). The complex has much lower solubility than protein, but higher surface activity. As the surfactant concentration rises throughout the aqueous phase, electrostatic interactions are complemented by hydrophobic ones. Thus, the complex becomes hydrophilic, and, accordingly, more water-soluble, and loses its surface activity. 
Summing up, it is to be noted that the analysis of the literature on rheological properties shows their important role in ensuring the stability of dispersion systems. It was found that the additional entry of polysaccharides or surfactants with different hydrophilic-lipophilic balance values to protein solutions enables to regulate adsorption of proteins and surfactants in the system, change the surface activity by forming protein-polysaccharide or proteinsurfactants complexes. It was established that in the literary sources most results are related to the use of non-food surfactants (sodium dodecylbenzenesulfonate) or those, restricted in their application - Tween-20, Tween-80, and also proteins as separate fractions. This approach allows for précising molecular interactions. However, to transfer them into foodstuffs, even to model systems requires some systematic experimental research.

\section{Conclusion}

1. The differences in the production of foams and emulsions are in the speed of dispersion. Emulsifying is faster than that of foaming, and the size of fat particles is smaller than that of air bubbles. Therefore, the production of foam emulsions food products, where emulsifying and foaming are simultaneous is impossible thermodynamically. The production must be performed sequentially.

2. The work systematized the factors, determining foam and emulsion destruction. The destruction factors are due to the properties and viscosity of the dispersion medium. Providing food products include both airy and fat phases, destruction will run faster.

3. The study systematized the factors, ensuring the stability of foams and emulsions. Multi-component food systems may feature several factors. The most considerable includes the varieties of the structural mechanical stabilization factor. It is implemented by the formation of a protection barrier on the dispersion particles via using only proteins, or solids with partial soaking (according to the Pickering stabilization), or combined use of proteins with low-molecular surfactants or the combined use of proteins and polysaccharides.

4. The production and stabilization of foam emulsions is to be based on the required spatial location of phases in the system, which is decisive for the foods textural properties. It is necessary to consider that this system contains phase boundaries of water-air and water-oil with varied difference of polarity. Thus, when selecting the kind and concentration of surfactants it is required to comply with the rheological properties of interface adsorption layers.

5. Interface properties of proteins and low-molecular surfactants specify rheological properties of interface adsorption layers, due to their kinds of adsorption (competitive, associative or layered), and their temperature-dependent surface activity. The rheological properties of interface adsorption layers play the leading role in the stability of foam emulsions, and foam emulsion suspensions.

6. The paper analyzed the methods of studying the rheological properties of interface adsorption layers. The values of viscosity, yield stress shear, and the elasticity modules correlate with the stability of foams and emulsions, and can be effectively used to forecast the stability of polyphase dispersion systems.

7. The rheological properties of interface adsorption layers are regulated by the addition of low-molecular surfactants with different hydrophilic-lipophilic балансу to the protein-containing systems, thus regulating adsorption, and the addition of polysaccharides, forming complexes throughout or at the boundaries of phases. 


\section{References}

1. Gilka-Bötzow A., Ukrainczyk N., Koenders E.A.B. Modelling Mineral Foam Morphology Dynamics for Stability and Insulation Properties, Conference: 4th Workshop on The New Boundaries of Structural Concrete - ACI Italy Chapter At: Anacapri, Italy, September 2016, Available at:

https://www.researchgate.net/publication/313248828_Modelling_Mineral_Foam_Morphology_ Dynamics_for_Stability_and_Insulation_Properties.

2. Murray B.S., Ettelaie R. (2004), Foam stability: Proteins and nanoparticles, Current Opinion in Colloid and Interface Science, 9(5), pp. 314-320.

3. Tadros, T.F. (2013), Emulsion formation and stability. John Wiley \& Sons, New York.

4. Burguera J. L., Burguera M. (2012) Analytical applications of emulsions and microemulsions, Talanta, Vol. 96, pp. 11-20.

5. Koroleva M. Iu., Iurtov E. V. (2012), Nanoemulsii: svoistva, metody polucheniia i perspektivnye oblasti primeneniia, Uspekhi khimii, 81(1), pp. 21-43.

6. Schramm L.L. (2006), Emulsions, Foams, and Suspensions: Fundamentals and Applications, WILEY-VCH Verlag GmbH \& Co, New York.

7. Kawakatsu T., Tragardh G., Tragardh C. (2001), The formation of oil droplets in a pectin solution and the viscosity of the oil-in-pectin solution emulsion, Journal of Food Engineering, 50, pp. 247-254.

8. Damodaran S., Paraf A. (1997), Protein-Stabilized Foams and Emulsions. In Food proteins and their applications, Marcel Dekker, New York.

9. Perrier-Comet J. M., Marie P., Gervais P. (2005), Comparison of emulsification efficiency of protein-stabilized oil-in-water emulsions using jet, high pressure and colloid mill homogenization, Journal of Food Engineering, 66, pp. 211-217.

10. Walstra P. (1993), Principles of emulsion formation, Chem. Eng. Sci., 48, pp. 333-349.

11. Prins A. (1999), Stagnant surface behaviour and its effect on foam and film stability, Colloids Surf, 149, pp. $467-473$.

12. Van Kalsbeek H.K.A.I., Prins A., Dickinson E., Rodriguez J.M. (1999), Foam formation by food proteins in relation to their dynamic surface behavior. In Food emulsions and foams: Interfaces, interactions and stability, Royal Society of Chemistry: Cambridge, pp. 91-103.

13. Velikov K.P., Velev O. D., Marinova K.G., Constantinides G. N., (1997), Effect of the surfactant concentration on the kinetic stability of thin foam and emulsion films, J. Chem. Soc., Faraday Trans, 93, pp. 2069-2075.

14. Xu W., Nikolov A., Wasan D.T. (2005), Shear-induced fat particle structure variation and the stability of food emulsions: II. Effects of surfactants, protein, and fat substitutes, Journal ofFood Engineering, 66, pp. 107-116.

15. Walstra P., Fennema O.R. (1996), Dispersed Systems: Basic Considerations. In Food Chemistry, Marcel Dekker: New York.

16. Kielczewska K., Kruk A., Czerniewicz M., Warmifska M., Haponiuk E. (2003), The effect of high-pressure homogenization on changes in milk colloidal and emulsifying systems, Polish Journal of Food and Nutrition Sciences, 12(1), pp. 43-46.

17. Cano-Ruiz M. E., Richter R. L. (1996), Effect of homogenization pressure on the milk fat globule membrane proteins, J. Dairy Sci, 80, pp. 2732-2739.

18. Boode K., Walstra P. (1993), Kinetics of partial coalescence in oil-in-water emulsions. In: Food Colloids and Polymers: Stability and Mechanical Properties, R. Soc. Chem., Cambridge, UK.

19. Boode K., Walstra P. (1993) Partial coalescence in oil-in-water emulsions 1. Nature of the aggregation, Colloids and Surfaces a-Physicochemical and Engineering Aspects, 81, pp. 121137.

20. Boode K., Walstra P., Degrootmostert A. E. A. (1993) Partial coalescence in oil- in-water emulsions 2. Influence of the properties of the fat, Colloids and Surfaces a-Physicochemical and Engineering Aspects, 81, pp. 139-151.

21. Wierenga P.A., Gruppen H. (2010) New views on foams from protein solutions, Current Opinion in Colloid \{\&\} Interface Science, 15(5), pp. 365-373. 
22. Kochetkova A.A. (2002), Pishchevye emulsii i emulgatory: nekotorye nauchnye obobshcheniia i prakticheskie podrobnosti, Pishchevye ingredienty. Syre i dobavki, 2, pp. 8-13.

23. Bhakta A., Ruckenstein E. (1997), Decay of standing foams: drainage, coalescence and collapse, Advances in Colloid and Interface Science, 70, pp. 1-124.

24. Cox S.J., Alonso M.D., Weaire D., Hutzler S. (2006), Drainage induced convection rolls in foams, The European Physical Journal, 19, pp. 17-22.

25. Volkert M. (2009), High pressure-low temperature induced structures in dairy foams and protein model systems. Diss. Technische Universität Berlin.

26. Weaire D., Hutzler S., Cox S., Kern N., Alonso M. D., Drenckhan W. (2003), The fluid dynamics of foams, Journal of Physics: Condensed Matter, 15, pp. S65-S73.

27. Weaire D., Vaza M. F., Teixeira P.I.C., Fortes M. A. (2007), Instabilities in liquid foams, Soft Matter, 3(1), pp. 47-57.

28. Pugh R.J. (1996) Foaming, foam films, antifoaming and defoaming, Advances Colloid and Interface Science, 64, pp. 67-142.

29. Santos S. F., Zanette D., Fischer H., Itri R. (2003), A systematic study of bovine serum albumin (BSA) and sodium dodecyl sulfate (SDS) interactions by surface tension and small angle X-ray scattering, J. Colloid Interface Science, 262, pp. 400-408.

30. Muller D., Malmsten M., Bergenstahl B., Hessing J., Olijve J. Mori F. (1998), Competitive Adsorption of Gelatin and Sodium Dodecylbenzenesulfonate at Hydrophobic Surfaces, Langmuir, 14, pp. 3107-3114.

31. McClements, D. J. (2016), Food Emulsion Principle, Practices, and Techniques, CRC, Boca Roton.

32. Walstra P. (1996), Emulsion stability. In: Encyclopedia of emulsion technology/Ed. By Becher P. New-York-Basel-Hong Kong: Marcel Dekker, 4, pp. 1-62.

33. Jackson N.E., Tucker Ch.L. (2003), A model for large deformation of an ellipsoidal droplet with interfacial tension, J. Rheol, 47, pp. 659-682.

34. Izmailova V.P., Iampolieskaia G.P, Summ B.D. (1988), Poverkhnostnye iavleniia v belkovykh sistemakh, Khimiia, Moskov.

35. Izmailova V.N, Rebinder P.A. (1974), Strukturoobrazovanie v belkovykh sistemakh, Nauka, Moskva.

36. Mishchuk N.A. (2011), The model of hydrophobic attraction in the framework of classical DLVO forces, Adv. Colloid Interface Sci, 168(1-2), pp. 149-166.

37. Babak V. G. (1992), Lineinoe natiazhenie v termodinamike tonkikh zhidkikh plenok, Uspekhi khimii, 61(10), pp. 1777-1804.

38. Wouters Arno GB, Rombouts I., Fierens E., Brijs K., Blecker C., Delcour J.A., Murray B.S. (2018) Foaming and air-water interfacial characteristics of solutions containing both gluten hydrolysate and egg white protein Food Hydrocolloids, 77, pp. 176-186.

39. Day L., Golding M., Xu M., Keogh J., Clifton P., Wooster T. J. (2014), Tailoring the digestion of structured emulsions using mixed monoglyceride-caseinate interfaces, Food Hydrocolloids, 36, pp. 151-161.

40. Tadros T. (2015), Viscoelastic properties of sterically stabilised emulsions and their stability, Advances in colloid and interface science, 222, pp. 692-708.

41. Wierenga P.A., L. van Norél, Basheva E.S. (2009), Reconsidering the importance of interfacial properties in foam stability, Colloids and Surfaces A: Physicochemical and Engineering Aspects, 344(1-3), pp. 72-78.

42. Cottrell T., J. Van Peij (2014), Emulsifiers in Food Technology, Blackwell Publishing Ltd, New Jersey.

43. Ettelaie R., Murray B.S. (2014), Effect of particle adsorption rates on the disproportionation process in pickering stabilised bubbles, Journal of Chemical Physics, 140(20), pp. 204713.

44. Jin H., Zhou, Cao J., Stoyanov S. D., Blijdenstein T.B. J, Groot P. W. N., Arnaudov L. N., Pelan E. W. G. (2012), Super stable foams stabilized by colloidal ethyl cellulose particles, Soft Matter, 8(7), pp. 2194-2205. 
45. Miller R., Fainerman V. B., Kovalchuk V. I., Grigoriev D. O., Leser M. E., Michel M. (2006) Composite interfacial layers containing micro-size and nano-size particles, Advances in colloid and interface science, 128-130, pp. 17-26.

46. Deshmukh O.S., D. van den Ende, M. C. Stuart, F. Mugele, M. H. G. Duits (2014), Hard and soft colloids at fluid interfaces: Adsorption, interactions, assembly $\{\&\}$ rheology, Advances in Colloid and Interface Science, 222, pp. 215-227.

47. Sagis L.M.C., Scholten E. (2014), Complex interfaces in food: Structure and mechanical properties, Trends in Food Science and Technology, 37(1), pp. 59-71.

48. Nushtaeva A.V. (2015), Pishchevye tverdye emulgatory, Universum: Khimiia i biologiia, 7(15), Available at: http://7universum.com/ru/nature/archive/item/2337.

49. Dickinson E. Hydrocolloids as emulsifiers and emulsion stabilizers, Food Hydrocolloids, 23(6), pp. 1473-1482.

50. YuanY., Oberholzer M.R., Lenhoff A.M. (2000), Size does matter: electrostatically determined surfacecoverage trends in protein and colloid adsorption, Colloids and Surfaces aPhysicochemical and Engineering Aspects, 165(1-3), pp. 125-141.

51. Diakina T.A., Derkach S.R., Levachev S.M. (2004), Kontsentrirovannye emulsii na osnove smesei zhelatiny s letsitinom: reologicheskie svoistva, Vesnik moskovskogo universiteta. Seriia 2. Khimiia, 45(1), pp. 58-63.

52. Laneuville S.I., Paquin, P., Turgeon, S.L. (2000), Effect of preparation conditions on the characteristics of whey protein-xanthan gum complexes, Food Hydrocolloids, 14, pp. 305-314.

53. Lii C.Y., Liaw S.C., Lai V.F., Tomasik T. (2002), Xanthan gum - gelatin complexes, European Polymer Journal, 38, pp. 1377-1381.

54. Nikolaeva O.V., Budtova T.V., Kaliuzhnaia L.M., Belkevich N.G., Vlasova E.N., Frenzel S.Ia. (1999), Mezhmolekuliarnye vzaimodeistviia v smesiakh polurazbavlenykh rastvorov poliakrilovoi kisloty i efirov tselliulozy, Vysokomolek. Soedineniia, 41(7), pp. 1176-1182.

55. Azarikia F., Abbasi S. (2016), Efficacy of whey protein-tragacanth on stabilization of oil-inwater emulsions: Comparison of mixed and layer by layer methods, Food Hydrocoll, 59, pp. 2634.

56. Patino J.M.R., Pilosof A.M.R. (2011), Protein-polysaccharide interactions at fluid interfaces, Hydrocoll., 25(8), pp. 1925-1937.

57. Izumrudov V.A., Zenin A.B., Kabanov V.A. (1983), Reaktsii obrazovaniia nestekhiometrichnykh polieletrolitnykh kompleksov, Vysokomolek. soedineniia, 25(9), pp. 1972-1978.

58. Goralchuk A.B., Pivovarov P.P. (2010), Tekhnologiia termostabilnikh emulsiinikh sousiv na osnovi ovochevoï sirovini, KhDUKhT, Kharkiv.

59. Tolstoguzov V.B. (1987), Nove formy belkovoi pishchi (Tekhnologicheskie problemy i perpektivy proizvodstva), Agropromizdat Moskov.

60. Maklakova A. A., Voronko N. G., Derkach S. R., Kadyrova G. I. (2014), Zotova Vzaimodeistvie zhelatiny s א-karraginanom po dannym IK-spektroskopii, Vestnik MGTU, 17(1), pp. 53-60.

61. Singh H., Tamehana M., Hemar Y., Munro P. A. (2003), Interfacial compositions, microstructures and properties of oil-in-water emulsions formed with mixtures of milk proteins and k-carrageenan: 1. Sodium caseinate, Food Hydrocolloids, 17(4), pp. 539-548.

62. Singh H., Tamehana M., Hemar Y., Munro P. A. (2003), Interfacial compositions, microstructures and properties of oil-in-water emulsions formed with mixtures of milk proteins and k-carrageenan: 2. Whey protein isolate (WPI), Food Hydrocolloids, 17(4), pp. 549-561.

63. Dickinson E., Pavvlowsky K. (1998), Influence of k-carrageenan on the properties of a proteinstabilized emulsion, Food Hydrocolloids, 12(4), pp. 417-423.

64. Dickinson E., in: P.A. Williams, G.O. Phillips (Eds.) (2004), Gums and Stabilisers for the Food Industry, Royal Society of Chemistry, Cambridge, UK.

65. Murray, B.S. (1998), Interfacial rheology of mixed food proteins and surfactant adsorption layers with respect to emulsion and foam stability, In Proteins and Liquid Interfaces, in "Studies of Interface Science”, 7, pp. 179-220.

66. Das K.P., Kinsclla J. E. (1990), Stability of food emulsions: physicochemical role of protein and nonprotein emulsifiers, Adv Food Nutr Res, 34, pp. 81. 
67. Dickinson E. (1998), Proteins at interfaces and in emulsion. Stability, rheology and interactions, J. Chem. Soc., Faraday Trans, 94(12), pp. 1657-1669.

68. Dickinson E., Ritzoulis C., Povey M.J.W. (1999), Stability of emulsions containing both sodium caseinate and Tween 20, J. Colloid Interface Sci, 212(2), pp. 515-529.

69. Dickinson E., Rad-ford S.J., Golding M. (2003), Stability and rheology of emulsions containing sodium caseinate: combined effects of ionic calcium and non-ionic surfactant, Food Hydrocolloids, 17(2), pp. 211-220.

70. Guzey D., McClements D. J. (2006), Formation, stability and properties of multilayer emulsions for application in the food industry, Advances in Colloid and Interface Science, pp. 227-248.

71. Rybak O. (2016) Milk fat in structure formation of dairy products: a review, Ukrainian food journal, 5(3), pp. 499-514.

72. Pareyt B., Finnie S. M., Putseys J. A., Delcour J. A. (2011), Lipids in bread making: Sources, interactions, and impact on bread quality, Journal of Cereal Science, 54, pp. 266-279.

73. Carr, N.O., Hogg W. F. (2005), A manufacturer's perspective on selected palm-based products, Asia Pac J Clin Nutr, 14(4), pp. 381-386.

74. Allen K.E., Murray B.S., Dickinson E. (2008), Development of a model whipped cream: Effects of emulsion droplet liquid/solid character and added hydrocolloid, Food Hydrocolloids, 22(4), pp. 690-699.

75. Denkov N. D., Marinova K. G., Tcholakova S. S. (2014), Mechanistic understanding of the modes of action of foam control agents, Adv. Colloid Interface Sci., 206, pp. 57-67.

76. Denkov N. D. (2004), Mechanisms of foam destruction by oil-bases antifoam, Langmuir, 20, pp. 9463-9505.

77. Hadjiiski A., Denkov N. D., Tcholakova S., Ivanov, I. B. (2002), Role of entry barriers in the foam destruction by oil drops, Marcel Dekker, New York.

78. Garrett P. R. (2014), The Science of Defoaming: Theory, Experiment and Applications, CRC Press, New York.

79. Hotrum N.E., Cohen Stuart M. A., Van Vliet T., Van Aken G. A. (2004), Spreading of partially crystallized oil droplets on an air/water interface, Colloids and Surfaces A: Physicochemical and Engineering Aspects, 240(1-3), pp. 83-92.

80. The Foam, (2009) IHC News, 4, Available at: http://www.clariant.com/C12575E4001FB2B8/ vwLookupDownloads/2009_01_IHC_Newsletter_Defoaming.pdf/\$FILE/2009_01_IHC_Newsl etter_Defoaming.pdf.

81. Arkhipov A. N. (2009), Primenenie strukturoobrazovatelei v proizvodstve molochnykh produktov, Tekhnika i tekhnologiia pishchevykh proizvodstv, 4. pp. 16-19.

82. Kaltsa O., Paximada P., Mandala I., Scholten E. (2014), Physical characteristics of submicron emulsions upon partial displacement of whey protein by a small molecular weight surfactant and pectin addition, Food Research International, 66, pp. 401-408.

83. Ralston J., Dukhin S.S., Mishchuk N.A. (2002), Wetting film stability and flotation kinetics, Advances in Colloid and Interface Science, 95(2-3), pp. 145-236.

84. Shahbazi B., Rezai B. (2015), The Effect of Micro Turbulence on Quartz Flotation Rate, Iran. J. Chem. \{\&\} Chem. Eng. English Ed, 34(3), pp. 79-89.

85. Albijanic B., Ozdemir O., Hampton M. A., Nguyen P.T., Nguyen A. V, Bradshaw D. (2014), Fundamental aspects of bubble-particle attachment mechanism in flotation separation, Miner. Eng, 65, pp. 187-195.

86. Rodionova N. S., Pashchenko L. P., Klimova E. A. (2009), Svoistva razlichnykh penoobrazovatelei v tekhnologii kislorodnykh kokteilei, Pivo i napitki, 5, pp. 20-21.

87. Dickinson E. (2012) Emulsion gels: The structuring of soft solids with protein-stabilized oil droplets. Food hydrocolloids, 28, pp. 224-241.

88. Dickinson E. (2019), Strategies to control and inhibit the flocculation of protein-stabilized oil-inwater emulsions. Food Hydrocolloids, 96, pp. 209-223.

89. Arboleya J-C., Ridout M. J., Wilde P. J. (2009), Rheological behaviour of aerated palm kernel oil/water emulsions. Food hydrocolloids, 23, pp. 1358-1365. 
90. Fredrick E., Heyman B., Moens K., Fischer S., Verwijlen T., Moldenaers P., Van der Meeren P., Dewettinck K. (2013), Monoacylglycerols in dairy recombined cream: II. The effect on partial coalescence and whipping properties, Food Res. Int, 51(2), pp. 936-945.

91. Prosekov A. Iu. (2005), Vliianie tekhnicheskikh kharakteristik rotorno-pulsatsionnogo apparata na strukturu vzbitogo produkta, Khranenie i pererabotka selskokhoziaistvennoi produktsii, 5, pp. 61-63.

92. Kakimov A. K., Kakimova Zh. Kh., Gaibalino G. M. (2008), Stabilizatsiia slivochnogo deserta, Molochnaia promyshlennost, 10, pp. 83-84.

93. Borcherding K., Lorenzen P., Offmann W. (2009), Effect of protein content, casein-whey protein ratio and $\mathrm{pH}$ value on the foaming properties of skimmed milk, International Journal of Dairy Technology, 62 (2), pp. 161-169

94. Erni P., Windhab E. J., Gunde R. (2007), Interfacial rheology of surface-active biopolymers: Acacia senegal versus hydrophobicallymodified starch, Biomacromolecules, 8, pp. 458-466.

95. Perez (2010), Interfacial and foaming characteristics of milk whey protein and polysaccharide mixed systems, AIChE Journal, 56(4), pp. 1107-1117.

96. Rodriguez Patino J. M., Rodriguez Nino M. R., Sanchez C. C. (2002), Static and dynamic properties of a whey protein isolate and monoglyceride mixed films at the air-water interface, Ind. Eng. Chem. Res, 41, pp. 297-303.

97. Kotlyar, O., Goralchuk A., Grynchenko O., Riabets O. (2014), Discourse of the form and concentration of surfactants to ensure the sustainability foam-emulsive products, Ukrainian food journal, 3(3), pp. 361-371.

98. Zhaoa Q. (2014), Frozen, chilled and spray dried emulsions for whipped cream: Influence of emulsion preservation approaches on product functionality, LWT - Food Science and Technology, 62(1), pp. 287-293.

99. Munka M., Erichsenb H., Andersen M. (2014), The effects of low-molecular-weight emulsifiers in $\mathrm{O} / \mathrm{W}$-emulsions on microviscosity of non-solidified oil in fat globules and the mobility of emulsifiers at the globule surfaces, Journal of Colloid and Interface Science, 419, pp. 134-141.

100. Méndez-Velasco C., Douglas Goff H. (2012), Fat structures as affected by unsaturated or saturated monoglyceride and their effect on ice cream structure, texture and stability, International Dairy Journal, 24(1), pp. 33-39.

101. Murray B. (2009), Bubble stability in the presence of oil-in-water emulsion droplets: Influence of surface shear versus dilatational rheology, Food Hydrocolloids, 23(4), pp. 1198-1208.

102. Xu R., Dickinson E. , Murray B. (2008), Morphological Changes in Adsorbed Protein Films at the Oil-Water Interface Subjected to Compression, Expansion, and Heat Processing, Langmuir, 24(5), pp. 1979-1988.

103. Fischer P., Windhab E. (2011), Rheology of food materials, Current Opinion in Colloid \& Interface Science, 16(1), pp. 36-40.

104. Horozov T. (2008), Foams and foam films stabilised by solid particles, Current Opinion in Colloid \& Interface Science, 13(3), pp. 134-140.

105. Kamath S. (2008), The influence of temperature on the foaming of milk, International Dairy Journal, 18(10-11), pp. 994-1002.

106. Chanamai R., Clements D. J. (2001), Prediction of emulsion colour from droplet characteristics: Monodisperse oil-in-water emulsions, Food Hydrocolloids, 15, pp. 83-92.

107. Müller-Fischer N., Windhab E. J. (2005), In fluence of process parameters on microstructure of food foam whipped in arotor-stator device with in awidestatic pressurerange, Colloids and Surfaces: Physicochemical and Engineering Aspects, 263, pp. 353-362.

108. Narchi I., Vial Ch., Labbafi M. (2011), Comparative study of the design of continuous aeration equipment for the production of food foams, Journal of Food Engineering, 102, pp. 105-114.

109. Sonntag N. (1982), Reactions of fats and fatty acids, Bailey's Industrial Oil and Fat Products, John Wiley \& Sons, New York.

110. Goh J., Kravchuk O., Deeth H. C. (2009), Comparison of mechanical agitation, steam injection andairbubbling for foaming milk of different types, Milch wissens chaft. Milk science international, 64, pp. 121-124. 
111. Indrawati L., Wang Z., Narsimhan G. (2008), Effect of processing parameters on foam formation using acontinuous system with amechanical whipper, Journal of food engineering, 88, pp.65-74.

112. Kreu M., Krauseb I., Kulozik U. (2009), Influence of glycosylation on foaming properties of bovine caseinomacropeptide, International Dairy Journal, 19(12), pp. 715-720.

113. Truong T., Bansal N., Bhandari B. (2014), Effect of emulsion droplet size on foaming properties of milk fat emulsions, Food and Bioprocess Technology, 7(12), pp. 3416-3428.

114. Xu D., Wang Xi., Jiang Ju., Yuan F., Gaoet Ya. (2012), Impact of whey protein-Beet pectin conjugation on the physicochemical stability of $\beta$-carotene emulsions. Food Hydrocolloids, 28(2), pp. 258-266.

115. Zhou Xi., Chen Li., Han J., Shi M., Wang Yu., Zhang L., Li Ya., Wu W. (2017), Stability and physical properties of recombined dairy cream: Effects of soybean lecithin. International Journal of Food Properties, 20(10), pp. 2223-2233.

116. Bai, Long, and McClements D. (2016), Extending emulsion functionality: post-homogenization modification of droplet properties. Processes, 4(17), pp.1-18.

117. Fameaua A., Salonen A. (2014), Effect of particles and aggregated structures on the foam stability and aging, Comptes Rendus Physique, 15(8-9), pp. 748-760.

118. Zhaoa Q. (2013), Effect of sorbitan monostearate on the physical characteristics and whipping properties of whipped cream, Food Chemistry, 141(3), pp. 1834-1840.

119. Creux P., (2009), Strong specific hydroxide ion binding at the pristine oil/water and air/water interfaces, J. Phys. Chem, 113(43), pp. 14146-14150.

120. Akartuna I. (2008), Stabilization of oil-in-water emulsions by colloidal particles modified with short amphiphiles, Langmuir, 24(14), pp. 7161-7168.

121. Cervantes Martinez A. (2008), On the origin of the remarkable stability of aqueous foams stabilised by nanoparticles: link with microscopic surface properties, Soft Matter, 4, pp. 15311535.

122. Fredricka E., Walstrab P., Dewettinck K. (2010), Factors governing partial coalescence in oil-inwater emulsions, Advances in Colloid and Interface Science, 153(1-2), pp. 30-42.

123. Yuan B. (2012), Effects of limited enzymatic hydrolysis with pepsin and high-pressure homogenization on the functional properties of soybean protein isolate, LWT-Food Science and Technology, 46(2), pp. 453-459.

124. Borcherding K., Lorenzen P., Hoffmann W. (2008), Effect of foaming temperature and varying time/temperature-conditions of preheating on the foaming properties of skimmed milk, International Dairy Journal, 18(4), pp. 349-358.

125. Nicorescu I. Influence of protein heat treatment on the continuous production of food foams, Food Res. Int, 43, pp. 1585-1593.

126. Barfod N. M., Schrader K., Buchheim W. (2000), Water continuous fat crystal networks in ice cream mix with unsaturated monoglyceridcs, Proceedings of the 2nd international Symposium on Food Rheology and Structur, Zurich, pp. 104-121.

127. Davies E., Dickinson E., Bee R. D. (2001), Orthokinetic destabilization of emulsions by saturated and unsaturated monoglycerides, Inc. Dairy Journal, 11, pp. 827-836.

128. Dickinson E. (2011), Food colloids research: Historical perspective and outlook, Advances in Colloid and Interface Science, 165(1), pp. 7-13.

129. Middelberg A. A., Dimitrijev-Dwyer M. (2011), Designed Biosurfactant Protein for Switchable Foam Control, ChemPhysChem, 12(8), pp. 1426-1429.

130. Huppertz T., (2010), Foaming properties of milk: A review of the influence of composition and processing. International Journal of Dairy Technology, 63(4), pp. 477-488.

131. Goralchuk A., Omel'chenko S., Grinchenko O., Mikhaylov V. (2016), Developing a model of the foam emulsion system and onfirming the role of the yield stress shear of interfacial adsorption layers to provide its formation and stability, Eastern-European Journal of Enterprise Technologies, 3(11), pp. 11-19.

132. Goralchuk A., Grinchenko O., Gubsky S., Tovma L., Zhuravl'ov S. (2017), Development of a model of steric stabilization of the air-nut semi-finished product structure, Eastern-European Journal of Enterprise Technologies, 3(11), pp. 11-17. 
133. Goralchuk A., Gubsky S., Tereshkin O., Kotlyar O., Omel'chenko S., Tovma L. (2017), Development of a theoretical model for obtaining the whipped emulsions from a dry fatcontaining mixture and its experimental verification, Eastern-European Journal of Enterprise Technologies, 2(10), pp. 12-19.

134. Izmailova V.N., Derkach S.R., Levachev S.M., Iampolskaia G.P., Tulovskaia Z.D., Kharlov A.E., Diakina T.A., Tarasevich B.N. (2002), Ustoichivost priamykh emulsii (maslo/voda), stabilizirovannykh zhelatinoi, Zhurnal prikladnoi fotografii, 47(6), pp. 38-73.

135. Dickinson, E. (1997) Floculation and competitive adsorption in a mixed polymer system. Relevance to casein-stabilized emulsions, J. Chem. Soc., Faraday Trans, 93(13), pp. 2297-2301.

136. Izmailova V.N., Yampolskaya G.P. (1998), Concentrated emulsions stabilized by macromolecules and the contributions of Hans Sonntag to this scientific field, Colloid \& Surfaces A, 142, pp. 125-134.

137. Langevin D. (2000), Influence of interfacial rheology on foam and emulsion properties, Advances in Colloid and Interface Science, 88(1-2), pp. 209-222.

138. Langevin D. (2011), Surface shear rheology of monolayers at the surface of water, Advances in Colloid and Interface Science, 207(1), pp. 121-130.

139. Langevin D., Monroy F. (2010), Interfacial rheology of polyelectrolytes and polymer monolayers at the air-water interface, Current Opinion in Colloid \{\&\} Interface Science, 15(4), pp. 283-293.

140. Miller R., Fainerman V.B., Leser M.E., Michel A. (2004), Surface tension of mixed non-ionic surfactant/protein solution: comparison of a simple theoretical model with experiments, Colloids \& Surfaces. A, Physicochemical and Engineering Aspects, 233, pp. 39-42.

141. Kovalchuk V.I., Miller R., Fainerman, Loglio G. (2005), Dilational rheology of adsorbed surfactant layers-role of the intrinsic two-dimensional compressibility, Advances in Colloid and Interface Science, 114-115, pp. 303-312.

142. Krägel J., Derkach S.R., Miller R. (2008) Interfacial shear rheology of protein-surfactant layers, Advances in colloid and interface science, 144(1-2), pp. 38-53.

143. Maldonado-Valderrama J., Fainerman V. B., Gálvez-Ruiz M. J., Martín-Rodriguez A., Cabrerizo-Vílchez M. A., Miller R. (2005), Dilatational Rheology of $\beta$-Casein Adsorbed Layers at Liquid-Fluid Interfaces, The Journal of Physical Chemistry B, 109(37), pp. 17608-17616.

144. Maldonado-Valderrama J., Patino J.M.R. (2010), Interfacial rheology of protein-surfactant mixtures, Current Opinion in Colloid and Interface Science, 15(4), pp. 271-282.

145. Miller R., Javadi A., Bastani D., Miller R., Kragel J., Javadi A., Bastani D., Miller R. (2010), Rheology of interfacial layers, Colloid and Polymer Science, 288(9), pp. 937-950.

146. Babak V.G. (1994), Stericheskaia stabilizatsiia zhidkikh plenok adsorbtsionnymi sloiami makromolekul, Uspekhi khimii, 63(3), c. 228-242.

147. Izmailova V.N, Iampolskaia G.P., Tulovskaia Z.D. (1998), Razvitie predstavlenii o roli strukturno-mekhanicheskogo barera po Rebinderu v ustoichivosti dispersii stabilizirovannykh belkami, Kolloidnyi zhurnal, 60(5), pp. 598-612.

148. Musabekov K.B., Zhubanov B.A., Izmailova V.K, Summ B.D. (1987), Mezhfaznye sloi polielektrolitov, Nauka, Alma-Ata.

149. Beverung C.J., Radke C.J., Blanch H.W. (1999), Protein adsorption at the oilrwater interface: characterization of adsorption kinetics by dynamic interfacial tension measurements, Biophysical Chemistry, 81, pp. 59-80.

150. Izmailova V.N., Malkova D. A., Iampolskaia G.P. (1987), Ustoichivost emulsii, stabilizirovannykh kazeinom, Kolloidnyi zhurnal, 49(1), pp. 151-153.

151. Dickinson E. (1992) Structure and composition of adsorbed protein layers and the relationship to emulsion stability, J. Chem. Soc. Faraday Trans, 88, pp. 2973-2983.

152. Dickinson E., Matsumura Y. (1991), Time-dependent polymerization of beta-lactoglobulin through disulphide bonds at the oil/water interface in emulsions, J. Biol. Macromol, 88(13), pp. $26-30$.

153. Izmailova V. N., Yampolskaya G. P. (1999), Rheological behavior of protein interfacial layers in emulsion stability, Applied Mechanics and Engineering, 4, pp. 141-144. 
154. Izmailova V.N., Yampolskaya G. P. (2000), Rheological parameters of protein interfacial layers as acriterion of the transition from stable emulsions to microemulsions, Adv. Colloid and Interface Sci, 88(1), pp. 99-128.

155. Derkach, S. R., Krägel J., R. Miller (2009), Methods of measuring rheological properties of interfacial layers (Experimental methods of 2D rheology), Colloid J., 71(1), pp. 1-17.

156. Pelipenko J., Kristl J., Rošic R., Baumgartner S., Kocbek P. (2012), Interfacial rheology: an overview of measuring techniques and its role in dispersions and electrospinning, Acta Pharm, 62(2), pp. 123-140.

157. Danov, K. D., Kralchevsky P. A., Radulova G. M., Basheva E. S., Stoyanov S. D., Pelan E. G. (2015), Shear rheology of mixed protein adsorption layers vs their structure studied by surface force measurements, Adv. Colloid Interface Sci, 222(8), pp. 148-161.

158. Martin A., Bos M., Stuart M. C., Van Vliet T. (2002), Stress-strain curves of adsorbed protein layers at the air/water interface measured with surface shear rheology, Langmuir, 18(4), pp. $1238-1243$.

159. Stanimirova R.D., Marinova K. G., Danov K. D., Kralchevsky P. A., Basheva E. S., Stoyanov S. D., Pelan E. G. (2014), Competitive adsorption of the protein hydrophobin and an ionic surfactant: Parallel vs sequential adsorption and dilatational rheology, Colloids and Surfaces A: Physicochemical and Engineering Aspects, 457(1), pp. 307-317.

160. Radulova G.M., Golemanov K., Danov K. D., Kralchevsky P. A., Stoyanov S. D., Arnaudov L. N., Blijdenstein T. B. J., Pelan E. G., Lips A. (2012), Surface shear rheology of adsorption layers from the protein HFBII hydrophobin: Effect of added $\beta$-casein, Langmuir, 28(9), pp. 4168-4177.

161. Marinova K.G., Basheva E. S., Nenova B., Temelska M., Mirarefi A. Y., Campbell B. E., Ivanov I. B. (2009), Physico-chemical factors controlling the foamability and foam stability of milk proteins: Sodium caseinate and whey protein concentrates, Food Hydrocolloids, 23(7), pp. 1864 1876.

162. Murray B.S., Durga K., Yusoff A., Stoyanov S. D. (2011), Stabilization of foams and emulsions by mixtures of surface active food-grade particles and proteins, Food Hydrocolloids, 25(4), pp. $627-638$.

163. Rousseau D. (2000), Fat crystals and emulsion stability - a review, Food Research International, 33(1), pp. 3-14.

164. Santini E., Ravera F., Ferrari M., Stubenrauch C., Makievski A., Krägel J. (2007), A surface rheological study of non-ionic surfactants at the water-air interface and the stability of the corresponding thin foam films, Colloids Surfaces A Physicochem. Eng. Asp., 298(1-2), pp. 12 21.

165. Lexis M., Willenbacher N. (2014), Yield stress and elasticity of aqueous foams from protein and surfactant solutions - The role of continuous phase viscosity and interfacial properties, Colloids Surfaces A Physicochem. Eng. Asp., 459, pp. 177-185.

166. Maldonado-Valderrama J. , Martín-Rodriguez A., Gálvez-Ruiz M. J., Miller R., Langevin D., Cabrerizo-Vílchez M. A. (2008), Foams and emulsions of $\beta$-casein examined by interfacial rheology, Surfaces A Physicochem. Eng. Asp., 323(1-3), pp. 116-122.

167. Aksenenko E. V., Kovalchuk V. I., Fainerman V. B., Miller R. (2006), Surface dilational rheology of mixed adsorption layers at liquid interfaces, Adv. Colloid Interface Sci., 122(1-3), pp. 57-66.

168. Carrillo-Navas H., Vernon-Carter E.J., Alvarez-Ramírez J. (2014), Viscoelastic retardation spectra of interfaces formed by water/glycerol monostearate crystals in canola oil dispersions, Colloids and Surfaces A: Physicochemical and Engineering Aspects, 441, pp. 1-7.

169. Goralchuk A.B., Pivovarov P.P., Prasol D.Iu. (2008), Doslidzhennia reologichnikh vlastivostei mizhfaznikh adsorbtsiinikh shariv dlia obghruntuvannja parametriv virobnitstva gariachikh emulsiinikh sousiv, Obladnannia ta tekhnologhiji kharchovikh virobnitstv, 18, pp. 234-240.

170. Golemanov K., Tcholakova S. S., Denkov N. D., Pelan E., Stoyanov S. D. (2014), The role of the hydrophobic phase in the unique rheological properties of saponin adsorption layers, Soft matter, 10, pp. 7034-7044.

171. Golemanov K., Tcholakova S. S., N. D. Denkov, Pelan E., Stoyanov S. D. (2013), Remarkably high surface visco-elasticity of adsorption layers of triterpenoid saponins, Soft Matter, 9(24), pp. $5738-5752$. 
172. L'opez-Castejon M.L., FACuente J., Ruiz M., Guerrero A. (2012), Influence of the presence of monoglyceride on interfacial properties of soy protein isolate, Journal of the Science of Food and Agriculture, 92(13), pp. 2618-2623.

173. Fainerman V.B., Aksenenko E. V., Lylyk S. V., Lotfi M., Miller R. (2015), Adsorption of proteins at the solution/air interface influenced by added nonionic surfactants at very low concentrations for both components. 3. Dilational surface rheology, The Journal of Physical Chemistry B, 119(9), pp. 3768-3775.

174. Dan A., Gochev G., Miller R. (2015), Tensiometry and dilational rheology of mixed $\beta$ lactoglobulin/ionic surfactant adsorption layers at water/air and water/hexane interfaces, Journal of Colloid and Interface Science, 449, pp. 383-391.

175. Noskov B.A. (2010), Dilational surface rheology of polymer and polymer/surfactant solutions, Curr. Opin. Colloid \{\&\} Interface Sci, 15(4), pp. 229-236.

176. Diez-Pascual A.M., Monroy F., Ortega F., Rubio R. G., Miller R., Noskov B. A. (2007), Adsorption of water-soluble polymers with surfactant character. Dilational viscoelasticity, Langmuir, 23(7), pp. 3802-3808.

177. Mucic N., Javadi A., Kovalchuk N. M., Aksenenko E. V., Miller R. (2011), Dynamics of interfacial layers-Experimental feasibilities of adsorption kinetics and dilational rheology, Advances in Colloid and Interface Science, 168(1-2), pp. 167-178.

178. Wustneck R., Kragel J. (1998) Proteins and Liquid Interfaces, Studies of Interface Science, 7, pp. 433-490.

179. Cheng J., Ma Y., Li X., Yan T., Cui J. (2015), Effects of milk protein-polysaccharide interactions on the stability of ice cream mix model systems, Food Hydrocolloids, 45, pp. 327-336.

180. Ganzevles R.A., Zinoviadou K., Van Vliet T., Stuart M. C., De Jongh H. H. J. (2006), Modulating surface rheology by electrostatic protein/polysaccharide interactions, Langmuir, 22(24), pp. 10089-10096.

181. Ghosh A.K. Polysaccharide-Protein Interactions and Their Relevance in Food Colloids, Bandyopadhyay in The Complex World of Polysaccharides, 14, pp. 395-408.

182. Chang Y., Hu Y., McClements D.J. (2016), Competitive adsorption and displacement of anionic polysaccharides (fucoidan and gum arabic) on the surface of protein-coated lipid droplets, Food Hydrocolloids, 52, pp. 820-826.

183. Liang Y., Gillies G., Patel H., Matia-Merino L., Ye A., Golding M. (2014), Physical stability, microstructure and rheology of sodium-caseinate-stabilized emulsions as influenced by protein concentration and non-adsorbing polysaccharides, Food Hydrocolloids, 36, pp. 245-255.

184. Miquelim J.N., Lannes S.C.S., Mezzenga R. (2010), pH Influence on the stability of foams with protein-polysaccharide complexes at at their interfaces, Food Hydrocolloids, 24(4), pp. 398-405.

185. Kelley D., McClements D.J. (2003), Interactions of bovine serum albumin with ionic surfacatants in aqueous solutions, Food Hydrocolloids, 17, pp. 73-85.

186. Miller R., Fainerman V. B., Makievski A. V., Krägel J., Grigoriev D. O., Kazakov V. N., Sinyachenko O. V. (2000), Dynamics of protein and mixed protein/surfactant adsorption layers at the water/fluid interface, Advances in Colloid and Interface Science, 86(1-2), pp. 39-82.

187. Levachev S. M., Izmailova V. N. (1994), Nekotorye svoistva assotsiatov bychego syvorotochnogo albumina i lipidov (letsitin, kholesterin), Kolloid, zhurnal, 56(2), pp. 193-196.

188. Kotlyar O., Goralchuk A., Grinchenko O. (2014) The study of surface-activ agents impact on the strength of interfacial adsorption layers, The Advanced Science Journal, 10, pp. 37-42.

189. Omelchenko S. B., Goralchuk A. B. (2014), Vivchennia mizhfaznikh adsorbtsiinikh shariv z metoiu rozrobki tekhnologhiji molochnoji produkciji, Skhidno-Jevropejsjkyj zhurnal peredovikh tekhnologii, 5/11(71), pp. 46-51.

190. Izmailova V. N., Levachev S. M., Iampolskaia G. P., Gratskova I. A., Kapustina A.A., Nuss P. V., Martynova E. V., Adebaio G. (2000), Reologicheskie kharakteristiki adsorbtsionnykh sloev interpolimernykh assotsiatov syvorotochnogo albumina i polistirola na granitse faz voda/ksilol, Kolloidnyi Zhurnal, 62(1), pp. 70-77.

191. Kralovaa I., Sjöbloma J. (2009) Surfactants used in food industry: A review, Journal of Dispersion Science and Technology, 30(9), pp. 1363-1383. 
192. Dickinson E. (2001), Milk protein interfacial layers and the relationship to emulsion stability and rheology, Coll. Surf. B: Biointerfaces, 20, pp. 354-363.

193. Maldonado-Valderrama J., Langevin D. (2008), On the difference between foams stabilized by surfactants and whole casein or $\beta$-casein. Comparison of foams, foam Films, and liquid surfaces studies, J. Phys. Chem, 112 (13), pp. 3989-3996.

194. Dickinson E., Ritzoulis C. (2000), Creaming and rheology of oil-in-water emulsions containing sodium dodecyl sulfate and sodium caseinate, J. Colloid and Interface Sci, 224, pp. 148-154.

195. Dickinson E., S. T. Hong (1997), Influence of an anionic surfactant on the rheology of heat-set $\beta$-lactoglobulin-stabilized emulsion gels, Colloid and Surfaces A., 127, pp. 1-10.

196. Sabadosh G. O., Goralchuk A. B. (2009), Doslidzhennia mizhfaznikh vlastivostei bilkiv moloka u tekhnologhiji otrimannia molochnikh desertiv, Proghresyvni tekhnika ta tekhnologhiji kharchovykh vyrobnyctv restorannogho ghospodarstva i torghivli, 2(10), pp. 191-197.

197. Courthaudon J-L., Dickinson E., Christie W.W. (1991), Competitive adsorption of lecithin and p-casein in oil in water emulsions, Journal of Agriculture and Food Chemistry, 39, pp. 13651368.

198. Murray B.S., Cros L. (1998), Adsorption of $\beta$-lactoglobulin and $\beta$-casein to metal surfaces and their removal by a non-ionic surfactant, as monitored via a quartz crystal microbalance, Colloids and Surfaces B: Biointerfaces, 10(4), pp. 227-241.

199. Roth S. Dickinson E. (2000), Interfacial shear rheology of aged and heat-treated $\beta$-lactoglobulin films: displacement by nonionic surfactant, J. Agric. Food Chem., 48, pp. 1491-1497.

200. Semenova M. G., Antipova A. S., Belyakova L. E., Dickinson E., Brown R., Pelan E.G., Norton I. T. (1999), Effect of pectinate on properties of oil-in-water emulsions stabilized by $\alpha_{s 1}$-casein and $\beta$-casein. In Food emulsions and foams: interfaces, interactions and stability, Cambridge: The Royal Society of Chemistry, pp. 163-175.

201. Patino J., Nino R., Gomez J. (1997), Interfacial and foaming characteristics of protein-lipid systems, Food Hydrocolloids, 11, pp. 49-58.

202. Rouimi S., Schorsch C., Valentini C., Vaslin S. (2005), Foam stability and interfacial properties of milk protein-surfactant systems, Food Hydrocolloids, 19, pp. 467-478.

203. Clark D.C., Wilde P.J., Bergink-Martens D.J.M., Kokelaar A.J.J., Prins A. (1993), Surface dilatational behavior of aqueous solutions of $\beta$-lactoglobulin and Tween 20, In Food Colloids and Polymers: Stability and Mechanical Properties, pp. 354-364.

204. Maria E. F, Silva Da, Meirelies N. C. (2004), Interaction of non-ionic surfactants with hepatic CYP in Prochilodus scrofa, Toxicology in Vitro, 18, pp. 859-867.

205. Zadymova N.M., Iampolskaia T.P., Filatova L.Iu. (2006), Vzaimodeistvie bychego syvorotochnogo albumina $\mathrm{s}$ neionogennym PAV Tvin-80 v vodnykh rastvorakh: kompleksoobrazovanie i assotsiatsiia, Kolloidnyi Zhurnal, 68(2), pp. 187-197. 